University of Pennsylvania Carey Law School

Penn Law: Legal Scholarship Repository

Faculty Scholarship at Penn Law

2001

\title{
Islands of Conscious Power: Law, Norms, and the Self-Governing Corporation
}

\author{
Edward B. Rock \\ University of Pennsylvania Carey Law School \\ Michael L. Wachter \\ University of Pennsylvania Carey Law School
}

Follow this and additional works at: https://scholarship.law.upenn.edu/faculty_scholarship

Part of the Business Administration, Management, and Operations Commons, Business Organizations Law Commons, Corporate Finance Commons, Finance Commons, Law and Economics Commons, Organizational Behavior and Theory Commons, Other Economics Commons, and the Securities Law Commons

\section{Repository Citation}

Rock, Edward B. and Wachter, Michael L., "Islands of Conscious Power: Law, Norms, and the SelfGoverning Corporation" (2001). Faculty Scholarship at Penn Law. 910.

https://scholarship.law.upenn.edu/faculty_scholarship/910

This Article is brought to you for free and open access by Penn Law: Legal Scholarship Repository. It has been accepted for inclusion in Faculty Scholarship at Penn Law by an authorized administrator of Penn Law: Legal Scholarship Repository. For more information, please contact PennlawIR@law.upenn.edu. 


\title{
ARTICLES
}

\section{ISLANDS OF CONSCIOUS POWER: LAW, NORMS, AND THE SELF-GOVERNING CORPORATION}

\author{
EDWARD B. ROCK ${ }^{\dagger} \&$ MTCHAEL L. WACHTER ${ }^{\dagger}$
}

This Article provides a theory of the relation between legal and nonlegally enfortable mles and standards in the corporation, and then uses that theon to analyz' a variety of prominent features of corporate law. In the first Part, we draw on ruckut hraklopments in the theory of the finn to identify key problems facing partirifants in the firm. In developing this approach, we combine the "propenty riglits" strand in the theory of the firm with the transaction cost approach. From this perspective, the main issue is solving the related problems of coordinating activilik's, rhoosing the firm's assets, and developing appropriate incentives for sperific inurstinents. In Patt II, we argue that the firm so understood will largely be gowrmed through "norms," by which we mean "nonlegally enforceable rules and standards" ("NLERS"). Indeed, the raison d'être of firms is to replace legal/contractual governance of relations with NLERS. Using this framework, in Part III ure annlyze the duty of loyally. In Part $N$, we analyze the duty of care and the linsiuess judgment rule, along with a variety of other puzzling features of rmpornte law.

From our perspertive, corporate law can be understood as a remarkably sothistirated merlanism for facilitating governance by NLERS. Centralized managrment is us'd to determine the assets over which the comporation must have residunl rights of control and to develop a governance structure for protecting the matcl-inu'stments of insiders in these assets. Legal rules provide the default settings through which centralized management operate and prohibit non-pro-rata distributions ( $a$ combination of ex ante rules and the ex post duty of loyalty), which pushes controlling shareholders to maximize the value of the firm.

Having established an "incentive compatible" legal form that facilitates NIERS govemance, the law must be careful not to undermine that governance by

$\uparrow$ Profesvor of Law, Unversity of Pennsylvania Law School, and Co-Director, Institute for Law and Economics, University of Pennsylvania.

t† William B. Johnson Professor of Law and Economics, University of Pennsylkanix Law School, and Co-Director, Institute for Law and Economics, University of Pennisliania.

Thanks to Lisa Bernstein, Bob Cooter, Mel Eisenberg, Jesse Fried, Jeff Gordon, Larny Hamermesh, Ehud Kamar, Leo Katz, Mtichael Klausner, Eric Posner, Bob Rasmussen, Mark Roe, Norm Veasey, and to participants in workshops at Berkeley, Columbia, Harrard, Vanderbilt, Villanora, participants in the Institute for Law and Economic roundtable at Penn, and participants in this Symposium. This research was supported by the University of Pennsylvania's Institute for Law and Economics. 
midstream interference. Here, the duty of care and the business judgment rule are critical. The business judgment rule acts as a jurisdictional mule that facilitates a self-governing NLERS relationship by preventing parties from turming to thirdparty adjudicators. As such, it plays a role very similar to the role of the employment-at-will doctrine in employment law, and for the same reasons. This analysis trovides an extlanation for why the duty of care destite its appearance does not function as a negligence nule, and why linhility for directorial malmractire is so much less common than liability for other forms of professional malpractice, such as legal or medical malpractice.

The principal contexts in which the business judgment mule does not apply are situations in which NLERS governance breaks down, generally because of last period temptations to defect. The difference in the ability of NLERS to govern midstream and endgames provides the key to understanding a variety of comporate law puzzles. These puzzles include: the asymmetry between the legal standards governing purchases and sales of assets; the asymmetry between judicial review over decisions to resist all bids for control ("just say no") versus the review of sales of control; and the demand requirement in derivative litigation.

INTRODUCTION .1621

I. THEORIES OF THE FIRM AND THE PROBLEMS

THAT MUST BE SOLVED 1624

A. A Standard View.........................................................................1626

B. Limitations of the Nexus of Contracting Model .............................1628

C. Developments in the Theory of the Firm: Modern Approaches.........1630

1. Transaction Cost Theories.................................................1631

2. Property Rights Theories ..................................................1634

D. Why Are TCE and Property Rights Models Important for Corporate Law?...................................................................1637

II. THE FIRM AS A DOMAIN OF NLERS GOVERNANCE ..........................1640

A. A Note on Terminology ................................................................1640

B. What Are the NLERS of the Corporation? .......................................1642

1. Examples of Corporate NLERS ........................................1642

2. Elements of a Theory of NLERS Evolution..........................1644

C. Why NLERS?: Legal Enforcement and the Boundaries of the Firm

III. CREATING AND PRESERVING NONLEGALIY

ENFORCED CORPORATE GOVERNANCE.

A. The Statutory Solution....................................................................1654

B. The Duty of Loyalty.......................................................................1661

IN. THE DUTY OF CARE AND THE BUSINESS JUDGMENT RULE ..............1663

A. An Historic Speculation.............................................................1670

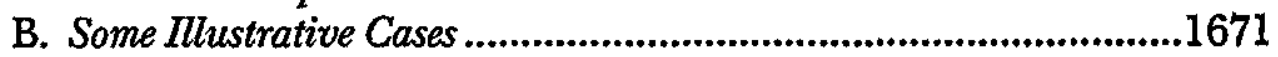

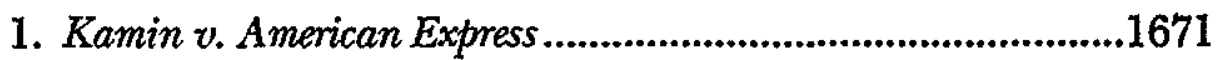

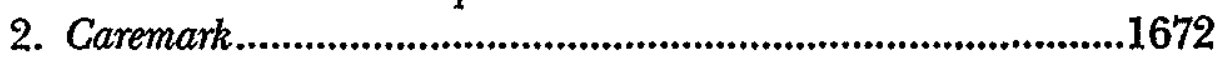

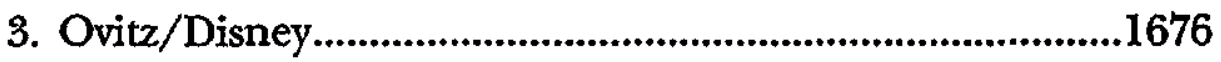

4. The Courts' Reluctance To Enjoin Dumb Decisions ........1680 


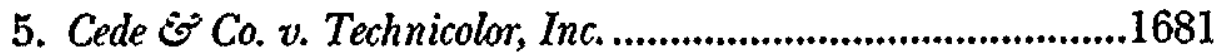

C. Limits of NLERS Governance: Midstream Versus Endgames.........1686

D. Some Other Puzzles: Asset Purchases, Failed Mergers, and "Just Saying No".

E. Delaware's Demand Requirement ...............................................1691

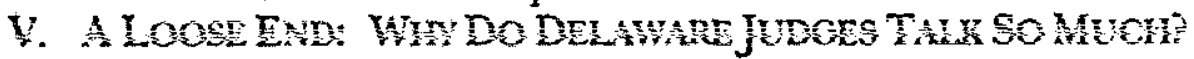

THE COURTS AND THE TRANSAISSTON OF NLERS

\section{INTRODUCTION}

Economic investigation of the nature of the firm is often traced to Coase's classic 1937 article, The Nature of the Firm. ' In it, Coase quotes the observation of D.H. Robertson that we find "islands of conscious power in this ocean of unconscious co-operation [that is, the market] like lumps of butter coagulating in a pail of buttermilk."'”2 Coase then famously asks, "But in view of the fact that it is usually argued that coordination will be done by the price mechanism, why is such organization necessary? Why are there these "islands of conscious power"?"”

Since Coase, economists have provided a great variety of theories that try to answer Coase's question, theories that are called "theories of the firm." A theory of the firm, by describing why we have firms, what goes on inside firms, and what are the boundaries of the firm, helps us identify the key problems that parties to the firm need to solve. A theory of the firm can also help us figure out what problems the parties are able to solve themselves, how they solve them, and the role the law plays in facilitating or interfering with solutions.

In this Article, we draw on recent developments in the theory of the firm and on the "law and norms" literature to explicate the core organizing role of centralized management and the facilitating role played by corporate law." Our central claim is the following: accord-

'Ronald Coase, The Nalure of the Firm, 4 ECONOMICA 386 (1937), reprinted in THE NATURE OF THE FIRM 18 (Oliver E. Williamson \& Sidney G. Winter eds., 1991).

" Id. at 19 (quoting D.H. ROBERTSON, THE CONTROL OF INDUSTRY 85 (1930)). Interestingly, Robertson then observes that "[t] he factory system itself, while it involves endless specialization of the work of ordinary men, involves also deliberate coordination of their diverse activities by the capitalist employer; and the head of a single big business to-day exercises a width and intensity of industrial rule which a Tudor monarch might have sighed for in vain." ROBERTSON, supra, at 85.

${ }^{3}$ Coase, supra note 1 , at 19.

'In drawing on this literature, we are not alone nor are we first. Important contributions that have drawn on these same models of the firm include: LUIGI ZNNGALES, CORPORITE GOVERNANCE (Nat'l Bureau of Econ. Research, Working Paper No. 6309, 
ing to an emerging consensus among theorists of the firm, the raison d'être of firms is to replace legal governance of relations with nonlegally enforceable governance mechanisms (what are sometimes called "norms"). Corporate law, we argue, should be understood as protecting and perfecting this choice. We show that understanding corporate law in this way allows one to explain a variety of features of corporate law that seem quite peculiar from the more traditional agency theory. These features include: the content and scope of the duty of loyalty; the fact that the duty of care, despite appearances, is not a negligence rule; the asymmetries in legal regulation of midstream versus endgame decisions, including "just saying no" and sales of divisions versus sales of companies; and the demand requirement in derivative suits. Our claim is not that agency costs are unimportant; indeed, in certain areas such as the duty of loyalty, agency concerns may be central. Rather, we argue, agency costs are not the only thing that matters in corporate law and, standing alone, are either unable to explain major areas of corporate law jurisprudence or are even misleading.

In this Article, we do not try to show all the implications of the emerging theory of the firm for corporate law. Here, we primarily use it to understand the duty of care, the business judgment rule, and companion doctrines. In later papers we intend to extend our analysis to other areas, such as the standards governing defensive tactics adopted by management to fend off hostile tender offers and the rules governing when shareholder ratification is required.

Theories of the firm teach us that for firms to exist and thrive, they must figure out how to encourage and protect specific investment in tangible and intangible assets. In Part I, we discuss the incompleteness of the "nexus of contracting" theory of the firm and offer a synthesis of the "property rights" and "transaction cost" theories that now represent the most complete explanation for why firms exist, what determines the boundary between firms and markets, and how firms survive in competitive markets.

1997); Margaret M. Blair \& Lynn A. Stout, A Team Production Theory of Corporate Law, 85 VA. L. REv. 247 (1999); William W. Bratton, Dividends, Noncontractibility, and Comporate Law, 19 CARDOzo L. REV. 409 (1997); William W. Bratton, Morten Hviid \& Joseph McCahery, Repeated Games, Social Norms, and Incomplete Corporate Contracts, in AsPECIS OF FAIRNESS IN CONTRACT 16I (Chris Willett ed., 1996); Melvin A. Eisenberg, The Conception That the Corporation Is a Nexus of Contracts, and the Dual Nature of the Firm, 24 J. CoRP. L. 819 (1999); Robert Flannigan, The Economic Structure of the Firm, 33 OSGOODE HALL, L.J. 105 (1995); Eric W. Orts, Shirking and Sharking: A Legal Theory of the Firm, 16 YALE L. \& POL'Y REV. 265 (1998). 
In Part II, we provide a bridge between the theory of the firm and the "norms" literature by arguing that the firm thus understood is a context in which governance will primarily be through "norms," by which we mean nonlegally enforceable rules and standards ("NLERS").

In Parts III and IV, we turn to corporate law and ask how corporate law helps solve the problems identified by the theories of the firm in Part I and how it facilitates the NLERS governance described in Part II. Using this perspective, we analyze the key features of corporate law including the default settings of the corporate form, the duty of loyalty, the duty of care and the business judgment rule, and the demand requirement in derivative suits. We also address a variety of puzzling asymmetries.

This approach casts a different light on the role and function of corporate law than the traditional agency cost approach. Viewed from this perspective, corporate law emerges as a remarkably sophisticated mechanism for facilitating self-governance by NLERS. Centralized management is used to determine the assets over which the corporation must have residual rights of control and to develop a governance structure for protecting the match-investments of insiders in these assets. Legal rules provide the default settings through which centralized management operate and prohibit non-pro-rata distributions (a combination of ex ante rules and the ex post duty of loyalty), which pushes controlling shareholders to maximize the value of the firm.

Having established an "incentive compatible" legal form within which governance is primarily by NLERS, the law must be careful not to undermine NLERS governance by midstream interference. Here, the duty of care and the business judgment rule are critical. The business judgment rule acts as a jurisdictional rule that facilitates a self governing NLERS relationship by preventing parties from turning to third-party adjudicators. As such, it plays a role very similar to the role of the employment-at-will doctrine in employment law and for the same reasons. The duty of care, despite looking like a typical legally enforceable standard of care, actually is best understood as an NLERS, with the business judgment rule assuring that enforcement is almost entirely nonlegal. This analysis explains why whole categories of cases are not brought (such as duty of care cases in response to disastrous mergers or investments), and why liability for directorial malpractice is so much less common than liability for other forms of professional malpractice, such as legal or medical. The principal situations in which the business judgment rule does not apply are situations in 
which NLERS governance breaks down, generally because of last period temptations to defect. Finally, it helps explain the very late appearance of the duty of care in Delaware law and the doctrinal tensions that continue to plague it.

Is a sense, thic Article is as much about what we do not see in corporate law as it is about what we see. That is, we are trying to understand both the cases that are brought and those that are not. This point is vital, as corporate lawyers are not primarily litigators. In many areas in which corporate law plays a central role, as in dealmaking, litigation takes a back seat and the number of important cases is small. That latter category-the "dark matter" of corporate law, the dogs that don't bark-is at least as important as the former. Why is this the case? Our theory of the firm offers an explanation.

\section{THEORIES OF THE FIRM AND THE PROBLEMS That MUST BE SOLVED}

What is the relation between the "theory of the firm" and corporate law? Oddly enough, despite years of corporate law scholarship that relies on the "theory of the firm," the question is not often asked. In the "corporation as contract" literature of ten years ago, Jensen and Meckling's agency cost analysis, elaborated in Theory of the Firm: Managerial Behavior, Agency Costs and Ownership Structure, played an important role. This role, however, was somewhat peculiar and secondary. It was as if everyone already knew (from Berle and Means) that the master problem of corporate law was agency costs, and along came an economic model and a vocabulary to elaborate that view. Even better, the model had some wonderfully provocative implications. Because we all already knew that corporate law was about minimizing agency costs, the model could be assimilated quickly.

In retrospect, two things are odd about this. First, as we discuss in more detail below, Jensen and Meckling, despite the title, did not really offer a full-fledged theory of the firm. Rather, they offered a theory of agency costs within firms, an important move that breathed life into the inert manager of the neoclassical model. In so doing, Jensen and Meckling dealt only with the agency relationship between the original owner/manager of the corporation and those to whom she sold equity (described as residual claims on the assets and cash flow of the organization) or debt. Nevertheless, they clearly understood these contracts as fitting into a broader nexus that included

${ }^{5}$ Michael C. Jensen \& William H. Meckling, Theony of the Firm: Managerial Behavior, Agency Costs and Oumership Structure, 3J. FIN. ECON. 305 (1976). 
suppliers, customers, et cetera. Jensen and Meckling used the phrase "nexus of contracts" to mean that a corporation's status as an entity had no economic meaning and that the corporation was, in their framework, nothing more than the contracts negotiated by the owner/manager."

Second, the use made of Jensen and Meckling's analysis by legal scholars did not follow at least one common form of law and economics arbitrage. Often, in law and economics, one identifies the "best" economic theory of a phenomenon and then asks how it advances our understanding of the law. In the case of Jensen and Meckling, it seems that an article that primarily focused on explicating the agency relationships within firms was taken by many legal scholars to be, itself, the best available theory of the firm. The nexus of contracts metaphor was adopted as corporate law's prevailing theory of the firm. Others, while perhaps acknowledging that the nexus was an incomplete theory of the firm, viewed it as a sufficient, partial theory because it addressed those aspects of the firm that were taken to be the (sole) topic of corporate law, namely the financial contract or relationship between shareholders and managers.

Thus, in rereading the definitive 1989 symposium in the Columbia Law Review on Contractual Freedom in Comporate Law, one finds a curious disconnect between the "law and economics" analyses and Oliver Hart's An Economist's Perspective on the Theory of the Firm. Legal scholars traded sharp words over the implications of the "nexus of contracting model" and over whether it provided an accurate description of the legal entity, the corporation. Meanwhile, the visiting economist, Oliver Hart, summarized his emerging synthesis of transaction cost and property rights theories of the firm, a synthesis in which Jensen and Meckling's agency cost analysis figures importantly, but in which the "nexus of contracting" model of the firm is dismissed as seriously incomplete. Hart's contribution to the symposium was largely ignored by the other participants.

What if, instead, one takes the theory of the firm as analytically prior? Suppose that one puts aside the assumption that corporate law is only about minimizing agency costs. If one does this, one looks to the theories of the firm to identify a set of problems that must be

"Ste' id. at 310 (" $[M]$ ost organizations are simply legal fictions which serve as a nexus for a set of contracting relationships among legal individuals ....").

${ }^{7}$ Symposium, Cantractual Freedom in Corporate Law, 89 COLUM. L. REV. 1395 (1989); Oliver Hart, An Economist's Perspective on the Theory of the Firm, 89 COLUM. L. REv. 1757 (1989). 
solved if firms are to exist and thrive. Having identified a set of problems, the theory or theories of the firm then provide a way of asking what corporate law is about, without assuming that we already know. In particular, it allows us to inquire into corporate law's role in helping the participants in the firm solve the key problems identified by the theory of the firm.

Our claim in this Article is not that agency costs do not matter in the firm, nor that corporate law does not address agency costs. Neither statement would be true. Rather, we argue, agency costs are not the only thing that matters in corporate law and, standing alone, are either unable to explain major areas of corporate law jurisprudence or are even misleading. Unless one places agency costs within an operational context, one will find all sorts of surprising absences and "failures" in corporate law. Agency cost analysis, alone, does not provide a framework within which Delaware courts can be understood as acting in an intelligent and principled way. Our claim in this Article is that the emerging theories of the firm, of which agency cost analysis forms a part (but only a part), are a more promising starting point and do a better job.

In the last fifteen years or so, there has been a flowering of economic analysis of the firm. Many of these efforts share a common preoccupation with endemic incompleteness of contracting and the resulting importance of "governance:" While the various analyses differ, both in detail as well as in core claims about what explains the existence and boundaries of firms, they share enough fundamental assumptions to provide a useful basis for exploring corporate law's role in the firm. In this Part, to provide a concrete example of these theories, we focus on the transaction cost theories of the firm associated with Oliver Williamson and his co-authors and the property rights theory of the firm associated with Oliver Hart and his co-authors.

\section{A. A Standard View}

Corporate governance has traditionally focused on the transactions between the executive officers, the board of directors, the shareholders, and the creditors. Issues involving the executive officers of the corporation and their management activities, while important, arise through the narrow lens that focuses on the agency relationship between them and the board-that is, the degree to which the interests of the managers are aligned with those of the shareholders. Topics involving the operating management of the company have been set outside the scope of corporate governance and of corporate law 
scholarship and teaching. This matches the standard casebook statement, that the corporate form is characterized by four characteristics: limited liability, free transferability, legal personality, and centralized management. This ordering matches the relative attention paid to each, with the greatest focus on the two initial features that describe the shareholders investment in the tirm. The ciscussion of centralized management, when it does arise, is an agency story that places shareholders on the outside attempting to control their agents.

This particularly narrow focus of corporate governance orves much to several factors. First, it reflects the enduring influence of Berle and Means. For nearly seventy years, corporate law has been defined by the "problem" of the separation of ownership and control.

Second, the paradigmatic corporation of corporate law is the publicly traded company with dispersed shareholders and, to a lesser extent, dispersed creditors. Shareholders invest in a diversified portfolio and, with little invested in any single corporation, do not take an active interest in or acquire knowledge of the operations of any of the companies. This is in contrast to the more intense relationship between the company and its employees, suppliers, customers, or even creditors. With ease of stock transferability, shareholders also have a lower cost to terminating their relationship with the company.

This has paved the way toward the current prevailing view of the corporation as a "nexus of contracts," with the contracts or agreements between the board of directors and the shareholders and creditors as the nodes of particular interest to corporate law. The many other nodes of the nexus fall into other categories: employment law, environmental law, and commercial law.

These influences are reinforcing: if shareholders have the least knowledge of the company and the lowest cost of exit, viewing their "contract" with the firm as just one of many has intuitive appeal. At the same time, the fact that shareholders are the "owners" of the corporation would seem to conflict with a description that minimizes their involvement. The answer, in the nexus of contracts approach, is that shareholders are ormers in the sense that they are the residual claimants with the associated right to vote on extraordinary matters like the sale of the company."

Examples of this ordering include WILLLAM L. CARY \& MELVIN ARON EISENBERG, CIUES LIVD ALITERLLLS ON CORPORITIONS 4-23 (7th ed. 1995), and ROBERT CHARLES CLLKK, CORPORITE LIW 117-20 (1986).

"St'FR LNK H. EASTERBROOK \& DANIEL R. FiSChel, THE ECONOMIC STRUCTURE OF CON'ORITE LIW 63-89 (1991) (examining the voting rights of shareholders). 


\section{B. Limitations of the Nexus of Contracting Model}

In its time, a central contribution of the nexus approach was to place the corporation into the grand scheme of equilibrating markets." The firm, as an organization, could be viewed as a collection of

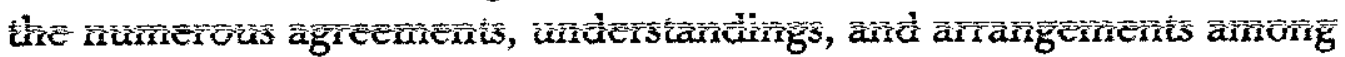
its members and between its members and its suppliers, customers, and others who interacted with it. Each of these was labeled as a contract as a matter of terminology. The "contracts" were assumed to be profit or utility maximizing for the individuals involved. The firm enters this picture as a coordinating organization. It would be wasteful for each of the employees, customers, suppliers, et cetera, to negotiate their own separate contracts. The firm, as an organization, provided the solution. Instead of numerous separate contracts, each actor negotiated a single contract with a firm that would then negotiate contracts with the other relevant firms or individuals, thereby saving on transaction costs. As a legal construct, the firm could be a partnership, corporation, or any of the various legal forms of organizations. In this general form, the relationships between the firm and its various counterparties are defined by their contracts."

As a continuing theory, the nexus of contracts serves as a powerful metaphor, focusing on the voluntary nature of the firm. As a positive statement, it describes statutes that regulate organizations as primarily enabling rather than mandatory, with individual terms serving as defaults which, while designed to meet the needs of most drafters, can be overwritten when they do not.

But as a motivating theory for corporate law or for business associations in general, a weakness of the nexus of contracts approach is that the firm as an operating unit appears to be without a core and without "insiders," as the term is normally understood." In the Jensen and Meckling article, as noted above, the only insider is the original manager/owner, who begins with $100 \%$ ownership and no debt, then sells equity and debt to others, and thereafter manages the firm as the agent of the shareholders. Because the nexus view defines the various constituencies by their contractual rights, the firm is merely the total

${ }^{10}$ See Jensen \&c Meckling, supra note 5; see also Hart, supra note 7.

"See EASTERBROOK \& FISCHEL, supra note 9, at 1-39 (discussing the corporate contract theory).

${ }^{12}$ It is as if one took as the paradigm case those firms that hold themselves out as being nothing more than a nexus of contracts, narnely general contractors whose only raison d'être is riding herd on subcontractors. This is a misleading way of thinking about firms in general. 
grouping of those relationships. In one respect, employees, including executive officers, are no more insiders than are individual suppliers, each described by their "contract" with the corporation.

As adapted to corporate law, the nexus of contracts theory of the firm is uninformative as to the corporation's economic function. By isolating the few contracts of interest, those between the corporation and its suppliers of financial equity and debt, the theory omits the nonfinancial operating and real capital transactions that drive the company's free cash flow and residual profits. This then leaves corporate law focused entirely on financial transactions that are cut off from the primary strategic operating transactions of the corporation. While this is unproblematic if one assumes that corporate law is only about the financial contract between the shareholders and managers, it prevents the nexus of contracts model from providing a framework within which one can analyze the role that corporate law potentially plays in the operating decisions of the firm.

Even more problematic, the nexus framework assumes away any meaningful internal governance mechanism. In the nexus model, the owner/manager's contract with the shareholders and creditors is assumed to be complete. Contract law is required, but only to enforce the contract as to its terms. Shareholders are also protected by their own monitoring efforts and by the bonding expenditures made by the owner/manager. These efforts do not require any enforcement, however, since, by assumption, when monitoring and bonding expenditures are made, the manager maximizes the interests of shareholders and does so without deviation. The same is true for the irreducible agency costs that remain after the parties engage in the optimal investments in monitoring and bonding. Here, however, the assumption is that the ormer/manager maximizes her utility function and does so without penalty. ${ }^{13}$ If corporate law (as distinct from contract enforcement) enters at all, it does so in the limited role of enforcing statutory requirements. ${ }^{14}$

Despite the strict and limited assumptions of the model, the corporate law scholarship that relies on it generally allows contractual incompleteness to creep in through the back door. Entering in this

is Jensen and Meckling do not deal with the issue of contractual incompleteness and, indeed, the issue is not raised in the article. They state: "[w]e focus in this paper on the behavioral implications of the property rights specified in the contracts between the owners and managers of the firm." Jensen \& Mleckling, supra note 5, at 308.

${ }^{i *}$ Ser id. at $311 \mathrm{n} .14$ (explaining the role played by the legal system in the organization of economic activity). 
fashion, related conceptual issues are ignored. The nexus's governance apparatus that deals with the incompleteness is assumed to be contractual, with courts filling in the contractual gaps more or less as they do in a commercial market context.

But the judicial role in the commercial market context assumes that gaps are small. If, instead, one assumes that the owner/manager has a great deal of discretion, the gaps become too large for gap filling. As we shall see below, in such a case the corporation must develop its own internal governance apparatus to resolve disputes. This apparatus may well operate in an entirely different manner than would be predicted by extending the market based nexus of contracts framework to allow for limited contractual incompleteness. Treating the two governance mechanisms as equivalent is incorrect. Indeed, as we shall discuss below, the differences in governance mechanisms between market contracts and intrafirm agreements explain some of the central "puzzles" in corporate law.

\section{Developments in the Theory of the Firm: Modern Approaches}

Two important theories of the firm-the property rights and transaction cost theories-present a very different picture of the firm than the "nexus of contracts" view. Although the theories were developed separately, they are highly complementary and, indeed, for our purposes can be viewed as a single theory. Whereas the property rights approach analyzes the role of physical and intangible capital, the transaction cost approach focuses more on human capital, specifically the employment relationship and the optimal degree of vertical integration with suppliers and business customers. In their respective domains, they share critical assumptions and develop complementary insights. Indeed, Hart and Moore view their property rights approach as building upon the transaction cost theory.

The critical insight shared by these approaches-as well as the complementary approaches of Holmstrom, Milgrom, and others working in this tradition-and which distinguishes these approaches from some of the other economic models of the firm, including most importantly the principal-agent models, is that contracting will inevitably be highly incomplete. Indeed, in these models, the core reason why transactions are brought within the firm is to solve problems created by the prohibitively high cost of complete contracting. As Holmstrom

${ }^{15}$ Oliver Hart \& John Moore, Property Rights and the Nature of the Firm, $98 \mathrm{~J}$. POL. ECON. 1119, 1120 (1990). 
puts it, "[w]hen contracts are incomplete in the sense that they cannot incorporate all future contracting opportunities, governance becomes consequential." The modes of coping with this inevitable contractual incompleteness-the adoption of nonlegally enforced governance structures-provide the basis for a positive theory of corporate law.

The starting point for all theories of the firm is the sparse outline provided by the neoclassical model. This model, which has been taught to generations of economists, depicts the firms as a set of production technologies or a production function. An unidentified manager buys inputs and sells outputs on its behalf. The agent in the nexus of contracts who negotiates all of the contracts of the nexus is borrowed from this theory. But, unlike the nexus theory, in the neoclassical view the firm has insiders. If one were to draw a picture of the firm, the firm's employees and its physical and intangible capital would appear inside the firm, while customers and suppliers would be outside. The theory, as first developed, provided an elegant mathematical expression for the firm that could be adapted to many markets and for many purposes. A weakness remained in the neoclassical theory: it said nothing about how the firm made decisions. It was the principal-agent model that first made the neoclassical theory come to life, modeling the potential conflict among the firm's main actors, the owners as principals and the senior managers and other employees as agents. The neoclassical firm coupled with the principal-agent problem has become the core to all other theories. ${ }^{1 \overline{7}}$

\section{Transaction Cost Theories}

Although, for our purposes, we treat the transaction cost and property rights approaches as a single theory, it is useful to show their separate roots and structures. The transaction cost theory of the firm was first developed by Coase in the 1930s and has been developed to its current state by Williamson and others working in that tradition. ${ }^{18}$

". Bengt Holmstrom, The Firm as a Subeconomy; 15 J.L. ECON. \& ORG. 74, 80 (1999).

${ }^{17}$ For an excellent discussion of the theory of the firm, see PAUL MILGROM \& JOHN ROBERTS, ECONOMICS, ORgaNIZATION, \& MANAGEMENT (1992). The text provides a detailed analysis of how the firm, a black box in the standard model, actually works.

"The transaction cost approach, and, indeed, the modern theory of the firm literature, begins with Coase, The Nature of the Firm. That article received little attention until it became a starting point for the seminal work of OLIVER E. WIILIAMSON, MLIRKETS AND HIERARCHIES: ANALYSIS AND ANTITRUST IMPLICATIONS (1975) [hereinaf- 
The main goal of the theory is to explain the optimal degree of vertical integration - that is, to explain why some activities are brought inside the firm and why some are left to the market. The discriminating factor is the level of transaction costs.

When transaction costs are low, the parties can write contingent state contracts to protect the integrity of their transactions. Transactions can thus be left in the market, with the market providing the parties with unequalled high-powered incentives for joint maximizing behavior. In addition, the parties can rely on market information to estimate asset values and opportunity costs. With information symmetrically available to the parties, the potential for opportunism diminishes and the reliability of third-party enforcement, should that prove necessary, increases. ${ }^{19}$

When transaction costs are high, the relationships are brought inside the firm where they are governed by the intrafirm, hierarchical governance structure. From the perspective of the transaction cost theories, the decision to bring relationships within the firm is just the decision to opt for the intrafirm governance structure over market governance. Transactions that have high costs are those involving high asset specificity, frequent transacting over a prolonged period of time, evolution of tasks over time, and connected joint outputs across participants. Asset specificity is a central feature because it often determines the intensity of the other factors. ${ }^{20}$ To a substantial extent, the ability of the firm to prosper in competitive markets depends on the productivity of its specific assets. Since others can reproduce general assets, they do not create a sustainable competitive advantage. Consequently, the more specific the assets to a particular transaction,

ter WIILIAMSON, MARKETS AND HIERARCHIES]. Williamson's work, defining the meaning of governance and working out its centrality in any theory of the firm, continues in OLIVER E. WILliAMSON, THE ECONOMIC INSTITUTIONS OF CAPITALISM (1985) and OLIVER E. WILLIAMSON, THE MECHANISMS OF GOVERNANCE (1996). See also KENNETH J. ARROW, THE LIMITS OF ORGANIZATION (1974); Armen A. Alchian \& Harold Demsetz, Production, Information Costs, and Economic Organization, 62 AM. ECON. REV. 777 (1972); Joseph E. Stiglitz, Incentives, Risk, and Information: Notes Towards a Theory of Hierarchy, 6 BELL J. ECON. 552 (1975); Oliver E. Williamson, Michael L. Wachter \& Jeffrey E. Harris, Understanding the Employment Relation: The Analysis of Idiosyncratic Exchange, 6 BELL J. ECON. 250 (1975). The roots of the Williamson approach may be found in HERBERT A. SiMON, ADMINISTRATIVE BEHAVIOR (3d ed. 1976).

19 See generally WILLLAMSON, MARKETS AND HIERARCHIES, supra note 18 (discussing the effect of disclosure on opportunistic behavior).

${ }^{2 \theta}$ An asset is a specific asset if an alternative user can only redeploy it with substantial sacrifice of productive value. An asset is general if there exists a ready secondary market so that the asset can be sold at approximately the firm's current use value. 
the greater the likelihood that the transaction will be brought inside the firm.

Consider, as an example, the case of Standard Supplier, a supplier of standard components to Network Switch, a company developing a new switch. Typically the supplier will make some investments learning about and working with the specific assets of their customer, but the level of such investments is likely to be low. In addition, the transactions between Standard Supplier and Network Switch are likely to be sporadic rather than continuing. In this context, contract writing is relatively inexpensive and the parties can write standardized contracts to protect their standardized transactions. In addition, various corporate law provisions that protect against shareholder-creditor opportunism, such as prohibiting the payment of excessive dividends or compensation and fraudulent conveyance law, help protect these contracts. Consequently, this relationship can be left to the market and Standard Supplier remains a separate corporation.

On the other hand, Specific Supplier makes specific components for Network Switch, a job that requires continuing contacts to keep abreast of changing market volumes and technological requirements. The more that a supplier works with and develops skills for Network Switch's specific assets, the more likely that the optimal arrangement is for the supplier's activity and workforce to be brought inside the firm. On the margin, Network Switch will offer to buy out Specific Supplier when the transaction costs of the external relationship are higher than the transaction costs that would result if the activity were internalized. In this fashion, according to the transaction cost theories, the boundaries of the firm are created and the optimal degree of vertical integration is set. ${ }^{21}$

The employment relationship is the single most important activity that is brought inside of the firm. Whereas firms could contract out all of its work, few do. Instead, employees are hired to work inside the firm. The primary reason is that employees themselves are making specific investments in their jobs. Because the employees are developing specific skills, the firm wants an ongoing relationship since it would be costly for new employees to learn the requisite skills. Transaction costs are high in the employment relationship due to the full range of factors that cause high transaction costs. ${ }^{22}$

${ }^{21}$ Benjamin Klein, Robert G. Crawford \& Armen A Alchian, Vertical Integration, Appropriable Rents, and the Competitive Contracting Process, 21 J.L. \& ECON. 297 (1978).

${ }_{22}$ Williamson, Wachter \& Harris, supra note 18, at 250. 
Central to the transaction cost approach is the use of hierarchy as the organizational structure to direct the overall activity of the various components, including employees, brought inside the firm. The hierarchy directs activity using self-enforcing rules and standards. It is this apparatus that replaces the market as the organizational mechanism for transacting: ${ }^{23}$

\section{Property Rights Theories}

The property rights theory developed by Sanford Grossman, Oliver Hart, and John Moore tells a similar story but leverages it off of control of specialized physical or intangible capital as opposed to the human capital basis of the transaction cost economics ("TCE") theories." In the property rights approach, the firm is defined by its technology. as is the case in the neoclassical model, but the technology is, in turn, identified with the physical and intangible assets (that is, the nonhuman capital) owned by the firm. As is true in the transaction cost theory, much of the relevant capital will be specific rather than general. Consequently, the contracts that describe the use of the capital will necessarily be incomplete. The key intuition is that nonhuman capital is the "core" of the firm-it provides the firm with competitive advantages and acts as the glue that binds employees to the firm. The property rights theory completes the transaction cost theory by explaining how bringing transactions within the firm solves the problems generated by investments in specific human capital.

Two concepts are of critical importance to this theory: contractual incompleteness and the right to decide issues not otherwise provided for by contract. For Hart and his co-authors, as well as others working in this area such as Rajan and Zingales, this residual right of control is what is meant by "power." Importantly, it includes control

${ }^{23}$ The importance of hierarchies and governance in the Williamson construct reveals itself in the titles of his major works, Markets and Hierarchies and The Merhanisms of Governance.

${ }_{24}$ The seminal contributions to this literature are Sanford J. Grossman \&. Oliver D. Hart, The Costs and Benefits of Owership: A Theory of Vertical and Lateral Integration, $94 \mathrm{~J}$. POL. ECON. 691 (1986), and Hart \& Moore, supra note 15. For a synthesis and elaboration of these ideas, see OLIVER HART, FIRMS, CONTRACTS, AND FINANCLAL STRUCTL RE (1995). See generally Holmstrom, supra note 16; Bengt Holmstrom \& Paul Milgrom, $T h$. Firm as an Incentive System, 84 AM. ECON. REV. 972 (1994); Raghuram G. Rajan \& Luigi Zingales, Power in a Theory of the Firm, 113 Q.J. ECON. 387 (1998) [hereinafter Rajan \& Zingales, Power]; Raghuram G. Rajan \& Luigi Zingales, The Firm as a Dedicated Hirrashy: A Theory of the Origins and Growth of Firms, 116 Q.J. ECON. (forthcoming 2001).

${ }^{25}$ See, e.g., HART, supra note 24 , at 4. 
over access to the specialized assets.

How, then, does a firm arise and survive in this model, and within what limits? We can only touch upon the key insights. Although some rights of control will be contracted for, other control rights will be ambiguous. As in the transaction cost theory, once contracts are

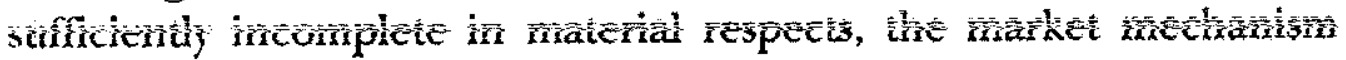
camnot be utilized (and vice versa). The market provides highpowered incentives and competitive discipline, but cannot solve unclear rights of control and provide for the organized use of capital. The solution is for one of the firms or agents who have some claim to the asset to buy the residual rights of control. As shown by Hart and Moore, the agent most likely to purchase the residual rights of control is the agent who either has the most invested, is the most indispensable of the parties with claims to the asset, or is best able to organize all of those with claims. ${ }^{2 / 1}$ As with the transaction cost analyses, here, too, the choice to bring the assets into the firm is a choice of a particular governance mechanism.

To see how the theory would operate, consider the case of an outside supplier whose semi-finished goods are highly specialized to work in the network switch. Ex ante, the parties cannot predict states of the world including changes in input qualities and quantities and cost changes. Since the component is highly specialized, the market cannot be used to assign the costs to one firm or the other. Incomplete contracts are the result. Remember that this means, in the world of the model, that contracts enforceable by third parties like courts cannot be written.

But in this situation, Network Switch might turn out to be an unreliable buyer or the outside component supplier might turn out to be an unreliable supplier. Disputes might arise as to the use of the specialized component or of the network switch which embodies it. Disputes and unreliability generate costs and decrease profits. Assuming that the component was highly specialized to Network Switch's needs, and that Network Switch was best able to organize its use, the assets would be purchased and would become part of the assets owned by Network Switch. With integrated control, Network Switch could then use centralized management and the authority relationship to direct production and use, while making an integrated assessment of full costs and revenues. ${ }^{27}$ In other words, the formation or expansion of

"Si"gurvally Hart \& Moore, supra note 15.

$A$ cost may be the loss of the supplier's personal labor services, but even this is 
the firm-the incorporation of the supplier's assets within the governance mechanism of the firm-is the solution to the incompleteness of the contracts.

To the property rights theorists, placing control over access to specialized nonhuman capital at the center of the theory of the firm resolves a critical weakness with the $\overline{T C E}$ theory. Since employees cannot constrain their basic right of job mobility, at least to any meaningful extent, human capital cannot be at the core of the firm-that is, it cannot be the defining feature of the firm. ${ }^{28}$ This relates to an objection raised by Alchian and Demsetz, who criticized the transaction cost theory on the grounds that it did not contain an explanation for why employees would follow the orders of the owners. For example, what prevents the specially skilled supplier/employee from holding up the firm even after being brought in? The brainy entrepreneur of Network Switch who threatens to defect is an illustration of the problem with putting human capital at the center of the firm.

The property rights answer is that employees will follow the orders of the asset owner because the owner can deny continued access to the assets in which the employee has already made investments or can grant access to even more valuable assets if the employee is a loyal and productive agent. Similarly, the brainy entrepreneur is less likely to defect because, in so doing, he will be forced to abandon important features of his physical capital inventions. This is a key move. Because the value of the specific human capital is tied to particular and nontransferable nonhuman capital, the problem raised in the Alchian and Demsetz objection is solved by bringing the nonhuman capital within the firm, where it serves as glue for the nontransferable specific human capital. ${ }^{29}$ By doing so, the firm's incentives to make relationshipspecific investments increase because it will capture a greater share of the surplus. ${ }^{30}$

less likely when her services are unique since the buyer can provide her with continued access to the resource. But, in any case, the employees of the supplier are now more valuable than before since the assets are now owned by the firm that values them most highly. Here again, the more specific their skills are to the assets being purchased, the more likely the employees are to remain with the purchaser. Central to the right of residual control is the right to grant or deny access to the use of the assets. Although employees with skills specific to the purchased assets can always quit, they are less likely to do so when the specificity of the skills is greater.

${ }^{28}$ Employment contracts help, but they only provide for damages, not for specific performance, if the employee decides to leave for a more attractive alternative job.

${ }_{29}$ See Holmstrom, supra note 16, at 75; Holmstrom \& Milgrom, supra note 24, at 972; Rajan \& Zingales, Power, supra note 24, at 387.

Although the residual claimant of the component supplier presumably was well 


\section{Why Are TCE and Property Rights Models Important for Corporate Law?}

Why should corporate law scholars care about the view of the firm that emerges from TCE and property rights theories? What is the connection between Part $I$ and the rest of this Article?

In order to undertand what comomate law does, one needs a model that describes the fim in a way that highlights the potential role of the law. Because the traditional neoclassical model of the firm assumes away all intrafirm complexity, it does not leave any role for the law and cannot form the basis for a positive theory of the law of the firm. ${ }^{\text {s }}$

served by the terms of the merger with Network Switch, how are the supplier's employees protected? Since they have made specialized investments, are they now unprotected? We worny that the company might use its rights of residual control to deny these employees any return from their asset specific investment.

One of the most intriguing results of the property rights theory is that employees of the supplier of specific component parts do better under unified ownership. In the nonmerged state the employees will lose if Network Switch acts opportunistically toward the supplier by imposing additional costs on it and if, in turn, the supplier passes on those costs to its employees. In addition, the supplier's employees are exposed to opportunism by the supplier to the extent that opportunism is not fully controlled by the selfenforcing terms of the supplier's internal governance apparatus. In general, when two firms are vulnerable to each other's opportunistic behavior, that vulnerability is indirectly passed on to the employees of both companies who are thus subject to holdups on the part of either company. Unified ownership of an asset reduces the number of points at which employees can be held up. Consequently, an immediate implication is that joint ownership is inferior to unified ornership.

The property rights theory also clears up another ambiguity present in the discussion of asset specificity. The parties who jointly make asset-specific investments do not jointly own the assets. One party buys the asset in the sense of buying the residual rights of control not otherwise ceded to others by contract. The omner can then direct its use. As noted above, joint ownership is inferior to unified owmership. Consequently, our specialized supplier is the ormer of the assets that create the semi-finished goods when she remains independent. When Network Switch purchases her assets, howerer, it acquires the residual rights of control. Similarly, employees will not jointly own the assets in which they and the firm make specific investments.

Resolving disputes over ownership, however, does not resolve the question over how match-specific participants are compensated. The previously independent supplier of semi-finished goods, now an employee of Network Switch, can be compensated based on performance, so that her compensation stream may have many of the attributes of her previous compensation stream. Similarly, employee compensation can be performance-based.

"A wonderful passage from Hart's Clarendon Lectures captures the problem of fit between analytic frameworks and the theory of the firm:

In this book, I will argue that these two ideas-contractual incompleteness and power-can be used to understand a number of economic institutions and arrangements. Before I develop this theme a little further, it is worth pointing out that power is not a standard feature of economic theory. For example, take the frameworks that economists use to analyse the behaviour of 
The principal-agent model captures some of the intrafirm complexity and is useful because the principal-agent problem is clearly a concern of corporate law. But, as Oliver Hart points out, the model assumes that the actors can write a complete contract that includes the appropriate penalties should anyone digress from the contract terms. In this world, courts and the law play an uninteresting role. Since the contract between the principal and the agent is complete, any action that would constitute breach is covered contractually by penalties that make such behavior unprofitable. If breach were to occur, presumably inadvertently, the court's role would be to do no more than read the contract and enforce the agreed-upon penaity. Within the world of the principal-agent models, because the focus is on capital structure and not on filling in gaps in contracts, it makes perfect sense to assume that contracts are essentially complete. For similar reasons, it is useful to assume away the firm-market boundary by conceptualizing the firm as a nexus of contracting.

This then is the problem: by assuming away contractual incompleteness and the firm-market boundary, the principal-agent model can neither provide a foundation for any theory that wishes to deal with a case in which pervasive contractual incompleteness is central nor explain why governance within the firm is any different than governance through markets. Perhaps for this reason, as noted above, the nexus of contracts approach ignores the difference between those agreements that are contracts, and thus meant to be legally enforceable, and those agreements that are not. Because of this, however, the

economic agents: general equilibrium theory, game theory, mechanism design or principal-agent theory, and transaction cost theory. In general equilibrium theory, it is supposed that trade takes place through anonymous competitive markets and that every agent abides by the terms of any transaction he or she enters into. In such a setting, power is irrelevant. In game theory, agents may have market power, i.e. the ability to affect price. However, market power is not the same as the notion of power used in this book. Market power captures the idea that the [building] contractor can charge my wife and me a lot for our house because there are not many competing contractors around; it says nothing about how we allocate power within our relationship. In mechanism design or principal-agent theory, it is supposed that it is costless to write a contract. An implication is that an optimal contract will be 'comprehensive', in the sense that, like the idealized house contract, it will lay down each person's obligations in every conceivable eventuality and impose large penalties if anybody fails to live up to them. But here again power is irrelevant, since an optimal comprehensive contract will not be breached or renegotiated.

HART, supra note 24, at 4 .

${ }^{32}$ Id. 
nexus of contracts view is limited in its ability to explain the role of the law in coping with contractual incompleteness. Furthermore, it is in the world of incomplete contracts that the dark matter of corporate law becomes primary. It is here, outside of contract, that many of the strategic operating decisions of the corporation are determined and

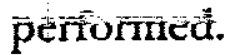

It is the TCE theory that first put contractual incompletenessand with it, governance-at the center of the theory of the firm. What, for corporate law purposes, does the property rights theory add? By providing a fuller answer to the question, "What is the firm?," it provides a model within which to ask the fundamental question, "What does corporate law do?"

Corporate law's version of the nexus of contracts theory provides the least satisfactory theory of the firm, essentially ignoring it. The TCE answer is that the firm should be thought of as the collection of activities brought inside the firm. The property rights theorists sharpen that answer down to the core: the firm is the collection of owned rights of residual control over intangible and physical capital.

In addition, the property rights model identifies a primary function of the firm as engaging in more or less continuous capital asset transactions. It is these key strategic operating decisions that provide the firm with the optimal collection of assets over which it needs to have residual control. The property rights model also places ownership (defined as the power to exercise residual control) at the core of the firm. Finally, the model starts from the assumption that "[i]n a corporation the shareholders as a group have control and delegate this control to the board of directors (i.e., management). ${ }^{\text {;33 }}$

Joined together, as we show below, the TCE and property rights models provide a foundation for a more comprehensive positive theory of corporate law. ${ }^{3-4}$ By focusing on contractual incompleteness, this theory begins with the intuition that the choice between intermarket and intrafirm transactions is the choice between relying primarily on legally enforced contract, on the one hand, and hierarchy,

"Grossman \& Hart, supra note 24, at 694.

${ }^{13}$ For our purposes, the differences among the various theories in this area are less important than the fundamental similarities. In this context, we can remain agnostic on the extent to which the property rights model, for example, is sufficient to explain why firms own essentially all nonhuman assets used in production and whether the model can explain not just what firms own but what they do (that is, which activities they engage in). For an important critique of the property rights models on these bases, among others, see Holmstrom, supra note 16. 
centralized management, and private governance on the other. By focusing on capital asset transactions, this theory highlights the major problems that need to be solved and the role of shareholders and managers. Although not a theory of law, it does provide the economic basis for a theory of corporate law that will illuminate both its role and content.

\section{The FIRM AS A DOMAIN OF NLERS GOVERNANCE}

The property-right/transaction-cost theory tells a compelling story about the boundaries and functions of the firm. Inside the firm, at its core, are the physical and intangible assets over which the firm owns the residual control rights. The individuals who work with these assets are primarily, but not always, employees of the firm. The central and defining transactions of the firm are those transactions that determine the set of assets over which the firm has residual control rights. Although wholesale acquisitions or divestitures are few, the firm continuously considers extending or refining the assets over which it needs the right of residual control.

In this context, the transactions between the firm and its suppliers, customers, and other parties who work outside of the boundaries of the firm are largely (but by no means entirely) governed by legally enforceable contracts. In contrast, the myriad transactions that take place inside the firm are largely (but not entirely) protected by a fundamentally different governance mechanism, one that is almost entirely not legally enforceable. In this Part, we examine the connection between legal and nonlegal governance of relations. As we discuss in more detail below, the tasks that the firm must solve, as described above, combined with the inevitable and far-reaching incompleteness of contractual relationships within the firm, render the firm a prime domain of nonlegally enforceable rules and standards.

\section{A. A Note on Terminology}

First, a few words about terminology. Economic theorists of the firm have long used the term "implicit contracts" to refer to nonlegally enforceable two-party relationships or agreements. Sometimes the phrase is used to refer to agreements that are literally selfenforcing, that is, agreements in which it is in neither party's interest to breach and which are thus enforced without any sort of third-party enforcement, legal or nonlegal. Sometimes the phrase is used more broadly to refer to all terms that are enforced by the parties to the re- 
lationship, often through reputational sanctions or self-help, without recourse to third-party adjudicators (judges or arbitrators).

From a legal perspective, the economist's phrase "implicit contract" is problematic. For lawyers, the term "contract" implies legal enforceability and the term "implicit contract" refers to legally en-

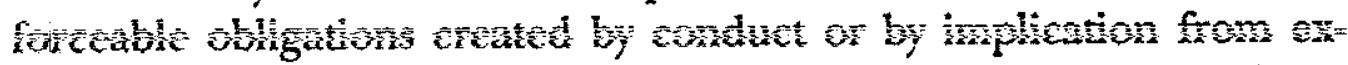
plicit contracts. One thus risks serious misunderstanding in utilizing the term for a mixed audience.

In the legal literature, of late, there has been much talk of "norms." This term is equally problematic. For economists, the term generally is taken to mean an observed behavioral regularity, such as the (fast eroding) norm of wearing neckties or of using umbrellas. For the general legal audience, the term frequently reflects an obligation: hence, there is a norm against murder.

But in the current legal literature on "norms," there is a separate, often intended meaning: namely, nonlegally enforceable rules or standards. In this context, the concern is the boundary between legal and nonlegal enforceability. The advantage of using the norms language is that it focuses attention on the boundary between legal and other third-party enforcement, just as the use of the implicit contracting language forces attention on the difference between self-enforcement and enforcement by third parties.

It is our sense that the terminology is hopelessly confusing and that we do best to avoid both "implicit contracts" and "norms." Instead, we will refer to "nonlegally enforceable rules and standards," which will be abbreviated "NLERS" (pronounced "N-lers"). NLERS come in different sorts. Some are truly self-enforcing in the sense that neither party has any incentive to breach. Some are self-enforced by feelings of guilt. Some are enforced directly by the parties themselves. Some are enforced by third parties through the application of peer pressure, shaming, or threats to one's reputation. None, by definition, is legally enforced. The phrase is thus helpful in posing the question of when parties do better relying on NLERS and when they do better relying on law.

We thus distinguish, on the one hand, between legal and nonlegally enforceable rules and standards and, on the other hand, between rules and standards and mere behavioral regularities. NLERS are thus understood to impose obligations, but without legal enforcement. 


\section{B. What Are the NLERS of the Corporation?}

\section{Examples of Corporate NLERS}

What are we talking about? What are examples of nonlegally enforceable rules and standards of the firm? What are the NLERS: To some extent, this will depend on the individual firm. For example, the famous dress code of IBM in the 1960s requiring white shirts, ties, and dark suits was an IBM-specific NLERS. Most everyone did it. you were expected to do it, and you were sanctioned, either formally or informally, if you did not. Less trivially, the promotion of teamwork is an NLERS practiced in many firms. Other firms, however, may promote individual effort.

One useful way of thinking of NLERS is that they form a great part of what is sometimes referred to as the firm's "corporate culture." Corporate culture can serve a coordinating function, making it more likely that employees will do what they are supposed to do when they are supposed to do it. NLERS play the intrafirm coordinating role that contracts play in market activity. Those that live up to or outperform the contract or NLERS expectations are credited, while those who do not are penalized with a range of sanctions including demotion, suspension, or dismissal. A principal difference, however, between NLERS and contracts is that when the parties disagree as to whether performance has been satisfied, courts can impose penalties in the latter case, but only the parties can do so in the former.

In origin, some NLERS are top-down, with senior management choosing and enforcing them. Others emerge bottom-up and might then be adopted and enforced by the firm. Still others can become a kind of counterculture, enforced not by the firm but by the employees themselves. For example, in some firms, work groups succeed in enforcing norms of not breaking production quotas.

Part of the role of centralized management is to choose the NLERS (encouraging productive NLERS and suppressing unproductive ones), just as it chooses the set of physical and intangible assets. Moreover, as we will see, one of the benefits of the deference afforded the internal governance of the firm is the possibility of different firms experimenting with different NLERS.

Within a firm, NLERS operate at many different levels. In other articles, we have written individually and together about the NLERS

${ }^{35}$ See Benjamin E. Hermalin, Economics $\mathcal{E}^{\circ}$ Corporate Cullure, in THE HANDBOOK of ORGANIZATIONAL CULTURE AND CIMATE (S. Cartwright et al., eds. 2001). 
that exist in employment relationships. For example, "discharge only for cause" in a world of employment-at-will is one of the prime NLERS that protects employees. ${ }^{36}$ Promotion from within to reward outstanding performance or seniority is another employment NLERS.

Other NLERS involve the manner in which the firm determines whether an investment project should be undertaken. Tine use of discounted present value for this purpose is an NLERS observed in many firms.

Still other NLERS exist in the corporate boardroom. Board composition itself is an NLERS. In many established firms, the board of directors is composed mainly of independent directors who have leading positions at other firms. In high-tech startups, the board is made up of strategic board members, including venture capitalists and outsiders who routinely deal with the firm as customers or co-joint adventurers.

NLERS also are not invariably efficient, socially beneficial, or conducive to the success of the firm. Some seem to help the firm succeed, like the NLERS of high-tech firms that lead engineers to work intensely on critical projects. Others may interfere with success, like the NLERS of not working too hard that emerges in some industrial work places. In historically regulated industries, all types of suboptimal, cost inefficient practices thrived and were protected and reinforced by the suppliers, unions, and others that benefited from them. These NLERS were sanctioned by the firms but were not socially efficient. For decades, racial, religious, and ethnic discrimination was an NLERS openly practiced by blue-chip firms. In some boardrooms, an NLERS is to accede to the wishes of the CEO regardless of her value to the firm. The decision by the board of Occidental Petroleum to build the Armand Hammer museum to house the CEO's unremarkable art collection was the result of such an NLERS. ${ }^{37}$ This type of NLERS is supportive of the executive officers but not the shareholders.

In addition to firm-specific NLERS, there also seem to be important transfirm NLERS. One way to identify such NLERS is to focus on the characteristic gap between articulated standards of conduct and actual liability standards. The most striking example of a transfirm NLERS of the corporation seems to be "maximize profits." How do

" Edward B. Rock \& Michael L. Wachter, The Enforceability of Norms and the Emflonment Relationshif, 144 U. PA. L. REV. 1913, 1930 (1996).

${ }^{7}$ See generally Kahn v. Sullivan, 594 A.2d 48, 51-58 (Del. 1991) (setting forth the story of the museum's construction). 
we know that this is a rule or standard of firms, and how do we know that it is nonlegally enforced? First, competitive theory tells us that only such firms will survive in competitive product markets. Thus, the emergence of the NLERS is Darwinian in the best sense of the term. That is, it has to be the rule, and we observe firms largely following the dictates. Moreover, business schools, among the most important teachers of NLERS, emphasize this commandment.

Is this NLERS nonlegally enforced? Again, the answer seems to be that it is. All sorts of features lead managers to maximize profits, while the courts are extremely reluctant to intervene in response to claims that managers have failed to do so. For example, the fact that shareholders are the residual beneficiaries, and only shareholders get to vote for directors, on mergers, and on dissolution, provides powerful pressure on managers to serve shareholders' financial interest. Yet, reliably, when individual shareholders complain that managers are not maximizing firm value because they are spending money on stupid investments, giving too much money to charity, or refusing to agree to a merger proposal, courts typically reject the claims. It is thus both a rule or standard and, at the same time, not legally enforceable. While stated rather vaguely, the profit maximization NLERS is actually reasonably specific. In its general form, it is taught in the standard MBA program.

Other examples of such NLERS include firms' active attempts to build core competencies that competitors cannot easily duplicate. Another is the use of present discounted value analysis to value new investment projects and to price assets. Such NLERS can be and are made very specific for particular situations. More generally, there are a host of business NLERS that provide the detail on how to maximize profits.

\section{Elements of a Theory of NLERS Evolution}

An adequate account of NLERS requires a theory of NLERS' suc-

${ }^{38}$ Another transfirm NLERS is maximizing shareholder value. This is one of several forms that the maximizing profits NLERS can take. During the heyday of the Berle-Means view of the corporation, it was generally believed that whereas firms might maximize profits, there was no reason for them to maximize shareholder value. Instead, profits could be used to increase the wealth or utility of the managers. To get from a world of profit maximization to a world of shareholder value maximization requires competitive capital markets or, more specifically, sufficiently deep capital markets that allow raiders to raise the financial capital necessary to make hostile tender offers. 
cess and failure both within and across firms. We cannot provide such an account in this paper: space does not permit, and we have not developed a good account yet, anyway. We can, however, touch upon several elements of such a theory.

A key element of a theory of corporate NLERS efficiency will be

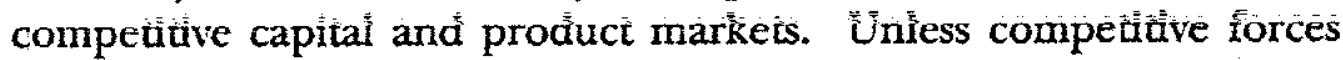
are operating, there is no particular reason to expect NLERS to be socially efficient. When markets are sufficiently competitive, a firm with suboptimal NLERS will be driven out of business.

A second element of such a theory will have to address how firmspecific NLERS spread from firm to firm. The diffusion of learning throughout the business world is how firm-specific NLERS become transfirm NLERS. Each firm does not somehow discover each term on its own. Senior executives learn of other firms' NLERS from other senior executives, by attending continuing business education sessions, or by hiring newly minted MBAs, engineers, and lawyers, who have been trained in the new techniques that work. These various channels provide a vibrant transmission mechanism that carries information on developing business practices and culture, that is, on developing NLERS.

When NLERS first appear, it is unlikely to be clear whether a particular NLERS will prove to be efficient or not. The competitive markets make the transmission mechanism more effective. Efficient NLERS are transmitted over the network without static and inefficient NLERS are transmitted with static. Take, for example, the diffusion of sophisticated corporate finance techniques. Competitive market discipline provides the motivating force. Over time, the efficient NLERS are heard by many firms and incorporated. Inefficient NLERS are sometimes heard and sometimes incorporated, but in the long run they are driven out of the market. Absent competitive markets, the transmission system would seed the business environment with a host of socially inefficient NLERS that might well survive. ${ }^{39}$

Furthermore, an exogenous shock can trigger a change in NLERS. Thus, one can observe changes in the NLERS governing senior managers and their compensation in response to the increasing competitiveness of the market for corporate control over the last thirty years. Thirty years ago, although senior executives typically worked without contracts and were, like all employees in the nonun-

"The courts and the law also play an important role in the NLERS transmission sy stem. This will be discussed in length below. See infra Part V. 
ion sector, governed by the legal doctrine of employment-at-will, the NLERS governing the termination of the CEO was approximately "discharge for cause," or perhaps the even less strict "discharge for extreme provocation." One regularly observed underperforming CEOs surviving until their retirement despite poor operating results and falling stock prices.

The change in the market for control changed the terms of the CEO's (nonlegally enforced) employment relationship. No longer could the underperforming CEO hold on, and even competent CEOs found themselves subject to untimely removal when their firms were acquired by a competitor. The hostile takeover element meant that a CEO could lose her job whenever the stock price fell far enough below fair market value to make a raid profitable. Such a price drop might be due to an overall market decline or the declining fortune of the industry, both unrelated to the performance of the CEO and the CEO's team.

As a high level of merger and acquisition activity became internalized as a persistent feature of the landscape, the terms of the CEO's employment relationship changed. The increased use of incentive compensation, including the vesting of unvested options upon a change of control, served two functions: (1) to align more closely the CEO's interests with those of the shareholders, thereby reducing the CEO's opposition to a value-increasing transaction; and (2) to compensate the CEO for what may be understood as discharge without cause, that is, a severance payment.

Just as the CEO's tenure became less settled, so too did the tenure of the senior executives who reported to the CEO and who often would be replaced after a new CEO was appointed. As with the NLERS governing the CEO, the NLERS governing these senior executives adjusted to the new reality, with similarly large increases in performance-based compensation.

The new compensation practices for senior executives were transmitted amazingly quickly to other firms through the use of compensation consultants and in response to a common set of external pressures. Equally striking, from our perspective, is how rarely the shareholders and bidders challenged these revolutionary changes in compensation structure and magnitude.

Were the changes in compensation packages a change in NLERS or merely a change in regularized behavioral patterns? Paying a market-based compensation package is not an NLERS. It is a behavioral regularity enforced by competitive markets. If the firm does not pay 
it, employees quit or do not seek employment there. The difference between the two is that if the practice is an NLERS, one party feels wronged and may seek to punish the other. Take, for example, the commitment to pay bonuses and to grant options based on the firm's or the individual's performance. If employees join Network Switch, assuming that good times for Network Switch will lead to large bonuses and the granting of a large number of options, and those bonuses are not paid or options granted during good times, then the employees will feel wronged and will seek to sanction the employer. An NLERS will have been violated.

A side feature of this example is that it shows how NLERS have gained increasingly wide acceptance, despite their private enforcement characteristics. Historically, payment of a weekly straight-time wage rate was the practice, and, if a firm defaulted on the commitment, the employee in many circumstances could seek legal redress. The switch to bonuses and options is a switch to a more NLERSintensive, nonlegally enforced compensation system. Although the terms of the options are legally enforceable, the number of options that are gxanted annually to employees is NLERS-enforced. Yet more and more of an employee's compensation, even at lower levels of the hierarchy, is NLERS-enforced pay-for-performance. Historically, the argument against performance-based pay turned less on the risk aversion of employees and more on the presumption that employers could not be trusted to live up to the bargain. ${ }^{* 0}$ Clearly, this has changed. Although employers may not be inherently more trustworthy, employees have indicated a greater willingness to rely on the NLERS enforcement mechanism.

\section{Why NLERS?: Legal Enforcement and the Boundaries of the Firm}

Why are the internal affairs of firms governed by NLERS? One answer is that it is the only option. As originally suggested by Coase and developed in detail by Williamson and others, transactions are brought inside the firm if it is too costly to write contracts that rely on competitive market discipline and judicial enforcement.

This insight has two facets. First, the market is unbeatable at its own game. In markets involving many buyers and sellers, whether in-

1" For a further discussion of incentive pay, see Edward B. Rock \& Michael $\mathrm{L}$. Wachter, Tailored Claims and Governance: The Fit Between Employees and Shareholders, in EMIPLOIEES AND CORPORATE GOVERNANCE 121 (Margaret M. Blair \& Mark J. Roe eds., 1999). 
volving inputs or outputs, the market price is the most reliable indicator of costs. When a transaction involves such inputs or outputs, a contract can be agreed upon that will reliably price expenses and revenues. Second, the market functions as its own command structure. This is captured beautifully by the nexus of contracts metaphor for the relationship between the corporation and its suppliers, customers, joint venture partners, et cetera. Supplies can be ordered, sales can be booked, and assets can be bought or sold. The market, by providing high-powered incentives to its participants, delivers performance. The courts, by providing remedies for breach that are based on market valuations of inputs and outputs, lend additionai incentives for the parties to deliver performance. When performance comes up short in a way that breaches a contract, the court steps in to provide remedies and penalties. Judicial success in providing adequate relief, however, is dependent on the market supplying correct and adequate opportunity cost data. Markets work best when they can rely on the law of contracts, and judicial enforcement of contract works best when it can rely on market valuations.

But there is a flip side to the power of the market. When inputs or outputs are specific to a transaction, when the number of transactions involving these specific inputs or outputs becomes large and complex, or when activities are complex and interrelated, the market mechanism begins to fail. Absent sufficient numbers of buyers and sellers, valuations become less dependable. The more numerous and complex are the specific transactions, the more costly is the writing of contracts. The market can only deliver performance, and the courts can only assist performance at high cost. As pointed out by Coase, Williamson, Hart, and others, when the costs are high enough the transaction is brought inside the firm.

For transactions inside the firm, the firm's authority structure replaces the market's command structure. Employees are hired and assigned to work with physical and intangible capital, intermediate goods are processed into finished goods, and decisions are made for the intended sale or purchase of assets through reliance on the authority of the firm's various decisionmakers. If sales decline or increase, inventory and capital are either idled or activated by executive decision and not by contract agreement among the affected parties. If employees, from executive officers to production workers, ignore orders or underperform, they are demoted, discharged, or otherwise penalized. The rare examples of legally enforceable employment contracts for specialized employees are the exceptions that prove the 
rule."

How does enforcement of NLERS work within the firm? The answer, mentioned in the prior Part, is the familiar story from the incentive compatible contracting literature. ${ }^{42}$ Governance arrangements are self-enforcing when one party cannot act opportunistically by shift-

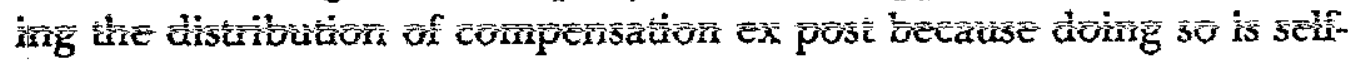
defeating. This is accomplished by embedding self-activating penaities whenever the bad agent acts opportunistically. When these are not available or are not for extra protection, the arrangements allow for self-help on the part of the imposed-upon agent. The high transaction costs that bring certain transactions inside the boundary of firms also create the ideal grounds for developing governance arrangements that are self-enforcing, encouraging good play and discouraging opportunistic play. For them to function properly, the ability to punish opportunistic play is important, and the highfrequency/long-duration interactions among the parties operating together inside the firm allow ample opportunity to sanction bad play and encourage good play. Similarly, frequent transacting also generates a high return for investing in a good reputation. ${ }^{43}$

Implicit, then, in the TCE/property rights theory of the firm is a theory of the judicial role. When contracting is complete, judges en-

1) In general, judicial intervention in intrafim transactions is driven by public policy concerns and is not chosen voluntarily by the parties themselves, except, as we discuss below, with respect to the duty of loyalty. See infra Part III.B. These occasions include the public policy exceptions to employment-at-will, the collective bargaining contracting system of the National Labor Relations Act, and the host of statutes imposing minimum standards on such terms and conditions of employment as retirement systems and occupational safety and health.

${ }^{12}$ See supra Part II.B.

43 A particularly important set of examples is the governance arrangement that operates in the employment relationship. An agent's marketability or bargaining power in the future will depend on factors that cannot be controlled via the original contract. The more specific are the assets, the more incomplete is the protection, since off-the-shelf contract terms are less helpful and contract outcomes cannot be reliably tied to external market outcomes. The high transaction cost setting of the employment relationship provides protection for employees who make asset-specific investments. Indeed, the firm's own internal labor market is replete with self-enforcing patterns of conduct. For more on how NLERS self enforce in the employment context, see generally Rock \& Wachter, supra note 36.

The property rights theory of the firm adds an additional dimension of enforcement. Excellent performance is rewarded by greater access, and inferior performance is penalized by less access. The arrangement is selfenforcing because the firm will want to retain its excellent performers while the excellent performers will want continued access or even greater access that enhances their marketability or bargaining power in the future. 
force those contracts. That is what makes contracts so valuable when they can be written. But when contracting is sufficiently incomplete, the enforcement is nonjudicial: either self-enforcement or enforcement through nonlegal means. In such circumstances, the role of the judge is "forbearance"-to leave the parties to work it out themselves:

In such a model, the roles of judges and senior managers are categorically different. Judges enforce contracts according to their terms. Senior managers exercise "power," deciding those issues relating to the deployment of the nonhuman assets and the associated human assets that have not been determined by contract. For judges to intervene in the exercise of that power is, in essence, a category mistake.

This notion of judicial role-which may seem crude, naive, or excessively modest to the sophisticated legal audience-flows directly from the core elements of the model. In these models, as described above, ${ }^{45}$ the boundary of the firm not only differentiates between centralized management versus markets as an organizing and directing mechanism, but also serves as a dividing line between two very different governance systems used to protect the integrity of the transactions. In the market, the courts or third-party arbitrators often resolve allegations of opportunistic behavior or contract breach. ${ }^{46}$ Inside the firm, self-enforcing rules and standards are used to ensure that investments in specific capital are protected. In other words, in this model, the boundary of the firm is a jurisdictional boundary chosen by the participants. Moreover, as we show below, however wooden or naive such a model may seem, it yields a powerful positive theory of corporate law. ${ }^{47}$

But why does the model anticipate a strict boundary? Why not let judges intervene just a little when, for example, parties' legitimate expectations have been disappointed? In the model, the firm is the solution to the problem of the organization of production when contracting is incomplete. The very problems of asset specificity and

* For an analysis of contract law from this perspective, see generally Alan Schwartz, Relational Contracts in the Courts: An Analysis of Incomplete Contracts and Judicial Strategies, 21 J. LEGAL STUD. 271 (1992).

45e supra Part I.

${ }^{46}$ But not always: in long term commercial relationships, as within the firm, parties often opt to solve such problems themselves without reference to third-party adjudicators.

${ }^{47}$ See infra Part III. 
asymmetry of information that make it impossible to write contracts and raise the challenge of incomplete contracting that leads to the emergence of the firm likewise imply a sharp boundary between legal and nonlegal governance. The factors that make it impossible for outsiders to determine reliably whether insiders have behaved badly also make it impossible for outsiders reliably to determine damages if they do decide that insiders have behaved badly.

Contractual incompleteness and judicial abstention are two sides of the same coin. In these models, contracts are incomplete when it is too costly to write complete contracts. The costs involved are, among others, the costs of judicial error. When, as in the firm, contracts are incomplete and the parties allocate the power of residual control by bringing a transaction within the firm, that power has not been delegated to third parties like judges. In this world, couris have but two roles to play: first, to enforce those contracts that are written, and second, to refuse to intervene when the power to decide has been allocated to a party as a solution to incomplete contracting.

There are two principal problems with selective intervention. First, decisions by centralized management often mean that someone is disappointed. If that someone can either reverse that decision by appeal to an outside party or use the appeal to an outside party to impose costs on other insiders, the internal balance will be upset. ${ }^{48} \mathrm{On}$ the substance, courts with inferior information will do systematically worse than the internal governance mechanism. Even worse, by allowing disappointed parties to appeal outside, the structure that forces the parties to work out their differences internally will be impaired.

But even worse than the inaccuracy and imbalance caused by selective judicial interference is the second principal problem with selective enforcement, the elimination of a valuable legal form. In the Williamson/Grossman-Hart-Moore ("GHM") models, the choice of bringing relationships within the firm just is the choice of a governance mechanism. If courts will selectively intervene at the behest of a disappointed party, that option will be destroyed. No longer will parties be able to opt for the nonlegally enforced governance system that the firm offers by bringing relationships into the firm. Instead, parties will either have to duplicate the self-governance by contracts explicitly prohibiting judicial intervention (if such contracts would be enforce-

That said, these models are consistent with courts and statutes setting bounds, whether in the form of OSHA or ERISA requirements or prohibitions on self-dealing by managers. Firms are assumed to form against some such backdrop. 
able) or bear the additional costs of not being able to adopt the optimal organizational form. ${ }^{49}$

What do we mean when we assert that conduct within the firm is governed by NLERS? Some, for example, might argue that such conduct is not dictated by NLERS but, rather, by selfinterest or by "the market." What work do we think NLERS are doing? At one level, the response is simple agreement: yes, in NLERS-governed transactions, it is in the self-interest of the parties to abide by the NLERS. But this answer, while accurate, may not be entirely helpful. NLERS are important because they transform agents' incentives so that they will find it in their self-interest to abide by the rule.

In this regard, the obligatoriness of NLERS within the firm plays the same role as the obligatoriness of contracts in market transactions. What work does contract law do in market transactions? Often it will be in the self-interest of the parties to fulfill contractual obligations. Sometimes it will be in the parties' interest only when market pressures are factored in. Sometimes, however, even when self-interest and market pressures are factored in, parties will still have an incentive to behave opportunistically, such as, for example, when performance is sequential. A party decides to perform rather than to breach the contract when performance is the profitable behavior. Contract law helps prevent opportunism by providing an extra incentive to perform.

This is all we mean when we say that a relationship within a firm is governed by NLERS. Suppose, for example, that it is an NLERS of the executive suite that investment proposals must pass a discounted cash flow ("DCF") test. Suppose a CEO is considering having the firm make a "vanity purchase" (say, a sports team) despite the fact that the purchase does not pass the DCF test, at least in part because of a willingness to overbid in order to satisfy the CEO's vanity. ${ }^{50}$ Assuming the firm is large enough (and with enough free cash flow) to crosssubsidize the sports team, the CEO's vanity would not be checked by the discipline of the product market. Similarly, although the stock price might drop a couple of points, that would not be enough to put the company into play, insulating the purchase from the discipline of the capital market.

49 For a fuller analysis, see generally Rock \& Wachter, supra note 36.

${ }^{50}$ Here we are assuming that the firm will not subsequently be able to resell the team for an even higher price to an even more vain entrepreneur, a price that will allow the firm to recoup its losses and make a profit. This assumption may not, in fact, be true. 
Yet, we find relatively few of these types of purchases. Because the board, in many (although not all) cases, might well turn down such a proposal, and might well hold it against the CEO if that person were already in trouble, the CEO is constrained from either proposing it or pushing it on a reluctant board. Here, it is not the product of capital

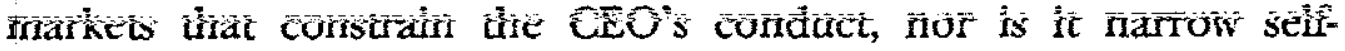
interest (the fun of owning the sports team might well outweigh the cost of a slightly lower stock price). Rather, when the sanctions for breaching the NLERS are taken into account, the CEO is discouraged from pursuing the investment. In other words, here, as in the contractual context, the NLERS helps support the relationship by providing an extra incentive to perform at crucial moments.

\section{CREATING AND PRESERVING NONLEGALLY ENFORCED CORPORATE GOVERNANCE}

It is often said that corporate law is the law that governs the internal affairs of the corporation. And yet it is our contention that the internal affairs of business organizations are primarily NLERS-governed. If we are right, what is the role of the law? How do the legal rules interact with the NLERS? Are they overlapping or do they operate in different spheres? When they overlap, are they essentially the same in content or do they conflict? In relationships governed by NLERS, understanding the role of the law is tricky. One must explore the extent to which the law facilitates or undermines the establishment and maintenance of the relationship."

In this Part, we ask how corporate law helps establish and maintain NLERS governance. Specifically, how does corporate law help to solve the governance problems identified above? When the firm sets out to attract employees and shareholders, many of whom will be strangers, how does the law help provide the foundations for developing nonlegally enforced corporate governance? The problem is to convince parties to make significant investments when the returns on those investments cannot be well-protected by contract and are thus subject to opportunistic behavior. How can one structure the relationship so that the executive officers, directors, and shareholders continue working in tandem, encouraging the managers to make ongoing specific investments while maximizing shareholder value? When the parties are contemplating investments they are acutely

St Set Eric A. Posner, The Regulation of Groups: The Influence of Legal and Nonlegal Sanctions on Collective Action, 63 U. CHI. L. REv. 133, 14465 (1996). 
aware of their vulnerability to ex post attempts to exploit the difference between use value and third-party liquidation value. The managers worry that the shareholders will threaten to force a sale to a third party as a way of forcing a redistribution of the surplus created by the match investments. The shareholders worry that the managers

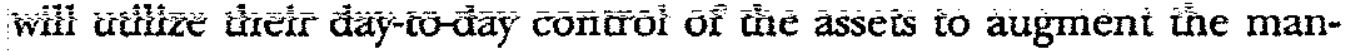
agers' return by reducing the residual available to the shareholders.

Note that we are not suggesting that there is a choice between NLERS and law. Nor are we claiming that NLERS and law need to work in two entirely separate spheres. The interplay of law in the form of enforceable rules and standards and NLERS is subtle, but it is critical. Consequently, we are asking what the relationship is between the two and claiming that legal rules can be understood as providing the framework within which NLERS governance occurs.

\section{A. The Statutory Solution}

The giant first step is the corporate form itself, a remarkable incentive-compatible device. The standard, off-the-rack, corporate form provides a robust first order solution to the key problems.

Consider the key features of the Delaware statute. The statute creates a legal person with certain characteristics. First, the statute creates an institution denominated the board of directors, which is endowed with the authority to manage the business and affairs of the corporation, including appointing officers. ${ }^{52}$

Second, the statute defines the role of shareholders. In the statutory scheme, shareholders play two principal roles: First and foremost, shareholders elect directors annually. ${ }^{53}$ In addition, shareholders have the power to veto board recommendations to amend the certificate of incorporation, ${ }^{54}$ to merge with another corporation, sell all or substantially all of the assets, ${ }^{56}$ and to dissolve the firm..$^{57}$ In practical terms, the requirement that shareholders approve amendments to the certificate of incorporation mainly means that shareholders get to vote on proposals to increase the number of authorized

\footnotetext{
${ }^{52}$ DEL. CODE ANN. tit. 8, § 141 (1991 \& Supp. 2000).

${ }^{53}$ Id. $\$ 211$ (Supp. 2000).

${ }^{54}$ Id. $\$ 242$ (1991 \& Supp. 2000).

Id. $\$ 251$.

${ }^{56}$ Id. $\$ 271$ (1991).

${ }^{57}$ Id. $\$ 275$.
} 
shares and on some takeover defenses. ${ }^{58}$

Equally important are the topics on which shareholders do not get to vote. Although shareholders get to vote on a sale of all or substantially all of the corporation's assets, the shareholders of the buying corporation do not get to vote, unless the purchase requires the issu-

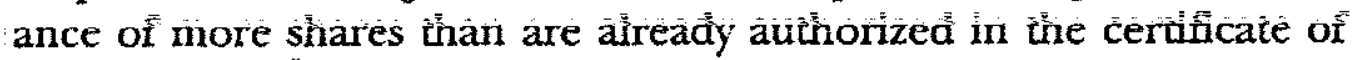
incorporation. Shareholders likewise do not have a right to vote on large investments or on the decision to borrow large sums of money, no matter how transformative of the nature of the enterprise such decisions may be.

Third, the statute provides that, upon dissolution, shareholders receive the assets remaining after all other claimants are paid. ${ }^{\text {i0 }}$ Prior to dissolution, the board has the power to declare dividends (pro rata distributions) to shareholders out of its "surplus."

Fourth, the statute limits the shareholders' power to initiate action. They cannot compel the dissolution of the firm, except by unanimous consent. ${ }^{62}$ They cannot compel the payment of dividends, nor veto a decision to pay dividends. In essence, they can only initiate two things: they can remove directors, with or without cause, ${ }^{63}$ and they have the undefined power to amend the bylaws, so long as the amendment is not inconsistent with the certificate of incorporation or the law."it

Finally, the statute limits shareholders' liability to the amounts inrested in the firm. ${ }^{65}$

$\therefore$ This is because, under section 102 , the certificate of incorporation must set forth "the total number of shares which the corporation shall have authority to issue." Id. $\$ 102$ (1991 \& Supp. 2000). In addition, due to a recent change in Delaware law, the certificate of incorporation may include a provision eliminating directors' liability for breaches of the duty of care. Id. $\$ 102(\mathrm{~b})$ (7) (Supp. 2000) (permitting amendment of the certificate of incorporation to "eliminat[e] or limit[] the personal liability of a director ... for breach of fiduciary duty as a director"). To add this provision to the certificate of incorporation of already existing corporations requires a shareholder vote.

Under stock exchange rules, shareholders have a right to vote if the transaction requires the issuance of more than twenty percent of outstanding shares, regardless of whether the certificate must be amended. N.Y. STOCK EXCHANGE, LISTED COAIPANY ALLNU,AL 1312.03 (1998). For similar rules for NASDAQ companies, see NASD Rules 4310 (c) (25)(H) (i) and 4460 (i) (1).

DEL. CODE ANN. tit. 8, $\$ \$ 275,280,281$ (1991 \& Supp. 2000).

i.l $I$ ld. $\$ 170$.

in Id. $\$ 278(\mathrm{c})(1991)$.

1.5 Id. \$141(k) (1991 \& Supp. 2000).

1"3 II. $\$ 109(1991)$.

Id. $\$ 102(\mathrm{~b})(6)$. 
Consider how this structure provides a first-order solution to the core governance problems identified earlier. Because the corporation is a legal person, it can hold property. When this is combined with the creation of the board of directors and the assignment to the board of decisionmaking power, the statute creates centralized management and assigns to that central management he nghis of residual control. ${ }^{\text {a. }}$ Without these features, which define, assign, and centralize the core property and control rights, Network Switch could not start to develop its novel switch. Every type of governance and management problem would emerge, from decisions as to how to attract and retain individuals willing to work with specific assets to questions of directing and coordinating the work needed to be done. In fact, however, these problems rarely emerge. Instead, the governance system with respect to physical and intangible investments works so smoothly that we often neglect to credit this accomplishment.

By creating the foundations for the firm to operate as a hierarchy, corporate law answers the question of who gets to "run" the company. The executive officers, appointed by the board of directors, "run" the company, in the manner outlined above in Part I. They determine both the core and the boundaries by deciding on the assets that need to be owned and the optimal degree of vertical integration (for example, which suppliers should be made employees). As such, the corporate form provides a legal infrastructure in which the GHM firm can emerge. If, as Hart argues, the (temporally and logically) first task is

66 In a pair of important articles triggered by and directed to the ALI Corporate Governance Project, Michael Dooley and Norman Veasey likewise focus on the importance of establishing and maintaining a decisionmaking structure conducive to efficient production. Michael P. Dooley, Two Models of Corporate Governance, 47 BUS. LAW. 461 (1992); Michael P. Dooley \& E. Norman Veasey, The Role of the Board in Derivative Litigation: Delaware Law and the Current ALI Proposals Compared, 44 BUS. LAW. 503 (1989). In their view, corporate law represents an uneasy compromise between the "authority model," which focuses on establishing and preserving the authority of the board of directors as a means of facilitating efficient production, and the "responsibility model," which focuses on deterring opportunistic conduct (both shirking and stealing) by agents. The business judgment rule and related doctrines such as the demand requirement in derivative litigation serve a dispute selection function necessary to preserve the board's authority. See generally Bayless Manning, The Business Judgment Rule and the Director's Duty of Attention: Time for Reality, 39 Bus. LAw. 1477 (1984).

Dooley and Veasey's approach is quite similar to ours. Our approach departs from theirs in the attention we give to the importance of NLERS governance in the firm. Once one recognizes that there is a robust, nonlegal set of mechanisms for constraining opportunistic behavior, the relationship between the authority model and the responsibility model need no longer be understood as a tradeoff. In so doing, we depart from the "legal centrism" that characterizes both the proponents and opponents of the ALI Principles of Corporate Governance. 
to choose the nonhuman asset set, ${ }^{67}$ the structure created by the statute allows this to occur.

Within this structure, an additional task of managers is to choose the NLERS that are to be used to protect the integrity of the transactions between the firm and its employees and shareholders. While the senior executives are severely constrained by both history and markets in making any of these critical decisions, they still retain significant discretion that can determine whether the firm succeeds or fails. Granting shareholders the right to elect directors, combined with the right to any assets remaining after dissolution and the payment of contractual claims, establishes the shareholders as the residuai claimants and provides them with the power to choose the objectives of the firm by choosing the directors.

In the close corporation or a public corporation with a controlling shareholder or group, shareholders can use their voting power to elect themselves to the board and appoint themselves as the executive officers. This creates an overlap between shareholders and officers that allows shareholders to be easily identified as the "owners" of the corporation in the sense used by Grossman and Hart.

At the same time, even in close corporations or corporations with a controlling shareholder group, the limitations on shareholders' ability to intervene, combined with the very small number of opportunities to vote beyond yoting on directors, protects the structure of centralized management by making it impossible for shareholders qua shareholders to exercise the power of residual control over the corporation's assets. As we have argued elsewhere, this prevents noncontrolling shareholders from acting opportunistically towards the controlling shareholder/managers. ${ }^{6 s}$

In the public corporation with dispersed shareholders, the statutory form creates a degree of discretion for the board of directors that does not exist in the close corporation. Because the shareholders, even acting collectively, do not have the power to instruct the board to undertake any specific course of action, the relationship between the shareholders and the board of directors is not one of principal and agent. This feature, combined with the infrequent occasions on

HART, supra note 24, at 29-30.

".4 Edward B. Rock \& Michael L. Wachter, Waiting for the Omelet To Set: MatchSprific Assets and Minority Oppression in Close Corporations, 24 J. CoRP. L. 913 (1999).

"' Melvin Aron Eisenberg, The Legal Roles of Shareholders and Management in Modem Corporate Decisionmaking, 57 CAL. L. REV. 1, 5 (1969) ("The board . . . is conceived to be an independent institution, not directly responsible to shareholders in the manner of 
which shareholders vote, prevents such shareholders from exercising the residual rights of control over the corporation's assets that characterize "Grossman and Hart" owners.

But does this discretion mean that shareholders in the publicly owned corporation with dispersed shareholders are just one stakeholder among many, with no greater ownership claims than, say, the creditors or the employees? In their article on "team production," Lynn Stout and Margaret Blair rely on the same property rights theories of the firm that we rely on to argue that the best way to understand the board's extensive discretion is to view the board of the publicly held corporation as a "mediating hierarchy" that balances the needs and entitlements of various participants in the firm. "In essence, they argue that the board should be viewed as an "honest broker," with the shareholders as merely one of many groups of stakeholders."

But the statutory form that so ably protects centralized management nonetheless provides dispersed shareholders with ownershiptype claims not available to any of the stakeholders that contract with the firm. While dispersed shareholders are not "Grossman and Hart" owners, they are much closer to being such owners than creditors or any of the other stakeholders except for senior management. ${ }^{72}$ On the one hand, the board, with its enormous discretion, has the ultimate responsibility and power to maximize the value of the corporation's assets and to craft the appropriate NLERS that protect the vulnerable specific investments of the various participants. But this needs to be done in a manner consistent with maximizing the shareholders' residual claim. If the directors fail to do so, shareholders can throw them out. That is why only shareholders get to vote for directors, a persistent feature of the corporate landscape. The fact that only shareholders get to vote is the critical feature of the standard corporation that fixes the goals of the board's exercise of discretion in draft-

an agent.").

Blair \& Stout, supra note 4, at 250-51.

${ }^{71}$ Id. at 298-309.

72 From a GHM perspective, the most plausible candidates for "owner" in the widely dispersed publicly held corporation are the executive managers who, in fact, get to decide questions not otherwise fixed by contract. From a purely descriptive perspective, especially given the possibility of management buyouts, one can view them as having the right to buy out the public shareholders, with the condition that a market test be satisfied. At the same time, public shareholders have some sort of call option on the assets of the firm that they can primarily exercise by selling to someone else, and every once in a while by voting out the old board. 
ing the NLERS of the firm. In light of this, while directors cannot be accurately described as agents of the shareholders, they can be understood to be the shareholders' elected trustees, and it is on their behalf that the directors manage or direct the use of the corporation's assets.

What is remarkable is how easily the statute protects centralized management while allowing sharehol̆ders a separate status. Shareholders, as shareholders, either are owners (in the close corporation) or have ormership-like rights in the form of sole voting porver to elect the board (in the publicly traded corporation with dispersed shareholders), and yet they do not exercise any functions of the centralized managers and do not make specific investments in the corporation's assets. This is different from the partnership form in which partners, as owners, have inherent rights to participate in management. In the corporate form, the shareholders have no such rights to participate, since that would conflict with the requirements of centralized management.

The standard terms of the statute resolve other governance questions as well. By providing the firm with an indefinite term of operation, the statute solves particularly acute problems involving opportunism that arise in the last period. Because dissolution requires a board resolution and a vote of a majority of the shares, individual minority shareholders have no power to trigger dissolution. Minority shareholders likewise have no right to be bought out because, under the standard corporation laws, no shareholder has a general right to be bought out. Together, these features prevent any individual noncontrolling shareholder from threatening dissolution in order to increase his share of the surplus.

The corporate form also handles the potential for opportunism by the controlling shareholders towards the noncontrolling shareholders. Here the critical mechanism is the prohibition on non-pro-rata distributions. Dividends, almost by definition, must be paid pro rata. Upon dissolution, anything left after creditors are paid off is distributed pro rata to the shareholders. Any selective distribution of assets to insiders is subject to special controls. ${ }^{73}$ Together, these terms provide a first-order solution to majority opportunism by yoking the interests of the controlling shareholder to those of the minority.

So long as non-pro-rata distributions are prohibited, the only way the controlling shareholder can benefit is by increasing the value of

"Ser, e.g., DEL. CODE ANN. tit. 8, $\$ 144$ (1991) (providing special procedures for the approval of interested transactions). 
the firm as a whole, thereby also benefiting the minority shareholders. To get money out of the firm, the controlling shareholder has two options. One is to pay out dividends, pro rata. The other is to dissolve the firm, which results in a pro rata distribution of the assets remaining after debts are discharged. ${ }^{7 /}$ The controlling shareholder can determine whether and when the firm is dissolved, but the distribution must be pro rata.

Finally, the corporate form mitigates the potential for opportunism by the board of directors toward noncontrolling shareholders. Although the board has the power to exercise centralized management, that right is limited to the business and affairs of the corporation and does not extend to a set of extraordinary transactions, particularly those involving last period transactions. For example, the board cannot amend the charter without the approval of the shareholders. Similarly, final period transactions, such as mergers, the sale of substantially all of the assets, and dissolution, also require the approval of shareholders. In addition, the general prohibition on non-pro-rata distributions applies to the board of directors and limits the directors' ability to favor one group of shareholders over another.

The earlier general discussion of NLERS explains why these must be legal terms. Because the gains of opportunism can be very largewhether in the form of the controlling shareholder stealing from the firm or of the minority shareholder holding up the controlling shareholder-NLERS sanctions may not be sufficient. ${ }^{75}$

${ }^{74}$ Stock buybacks provide another method but can jeopardize the controlling shareholder's control.

75 Could all this be accomplished by contract? The problem that leads to transactions being brought into the firm is pervasive contractual incompleteness. Now, how do parties respond to contractual incompleteness by contract? If the gaps are small, parties sometimes leave it to courts to fill in. If the gaps are large, the TCE literature argues that parties respond by establishing a governance mechanism to handle issues as they come up. One could, in principle, establish such a governance mechanism by contract. Indeed, in relational contracts, the parties sometimes do. In the relational contracting context, when gaps are large and the parties have opted for a nonlegal governance mechanism, the courts respect the contracting choice by saying that there is no enforceable contract. See generally Alan Schwartz, Relational Contracts in the Courts: An Analysis of Incomplete Agreements and Judicial Strategies, 21 J. LEGAL STUD. 271 (1992).

From this perspective, corporate law can be understood as a standard form contract to provide just such a governance mechanism by establishing actors and hierarchy. Such a view is entirely consistent both with freedom of contract and with the view of corporate law as a standard form contract. If courts then intervene in intrafirm disputes that are intended to be subject to the intrafirm (nonlegal) governance structure, a party breaches its agreement in asking, and courts are overriding the contracted for structure if they interfere. Interfering in such circumstances undermines the contractual choice. 


\section{B. The Duty of Loyalty}

Given the basic incentive compatibility of the corporate form and the extent to which it aligns the interests of shareholders and prevents opportunism, how does the classic fiduciary duty of loyalty fit into this picture? What is it role in preserving the posibility of NLERS goveniance over specific assets created by the corporate form itself Three goals must be kept in mind. First, the key coordinating function served by centralized management must be preserved. Second, minority and majority opportunism must both be discouraged. Third, the self-governing character of the relationship must be preserved.

From this perspective, the duty of loyalty is the second half of the prohibition on non-pro-rata distributions. The first piece, mentioned above, is the statutory requirement that dividends be paid out pro rata according to the number of shares, with the linked requirement that upon dissolution, all shareholders share the proceeds pro rata.

But there are a million and one ways to evade such a rule. The role of the duty of loyalty is to prevent enough instances of selfdealing from slipping through that the overall incentive compatibility of the form is not undermined. The form maintains its usefulness if some self-dealing gets through, but not if too much does.

Each of the major aspects of the duty of loyalty blocks one of the obvious modes of siphoning off assets. The limitations on basic selfdealing, coupled with criminal prohibitions of embezzlement, theft, and fraud, attempt to prevent the grossest sorts of theft while encouraging the use of processes that will preserve enough flexibility to allow those transactions that will benefit the firm. The treatment of compensation, similarly, is understood as a judicial attempt to prevent the worst sorts of self-dealing while allowing enough flexibility in structuring compensation to encourage managers to perform well. Finally, the various strands of the corporate opportunities doctrine seek to

From this perspective, opting into the corporate form is one way that one (contractually) opts into a particular governance mechanism. But opting into the corporate form as a means of opting into a particular governance mechanism may have some advantages over a custom drafted contract that go beyond simply the costs of drafting and the greater certainty of using commonly interpreted terms. See generally Michael Klausner, Corporations, Corporate Law, and Networks of Contracts, 81 VA. L. REV. 757 (1995).

To the extent that the paradigm case for contract law is spot contracting, the parties and the courts may expect the court to play a role in enforcing contracts that is more interventionist than in the typical corporate context. If this is right, then opting into the corporate form will provide greater assurance that judges will not override the parties' choice of governance mechanism by intervening. 
strike a similar balance.

Thus, the role of the duty of loyalty is to provide a check on directorial or controlling shareholder opportunism. Because of the potential gains from stealing, the check must be legal. But, at the same time, the check is constrained. The idea is to keep the director or controlling shareholder in the flock, working for the advantage of the group. The law plays the role of sheep dog, but does not intervene more than necessary.

Moreover, it is clear why these limitations must be legal. The possibility of self-dealing converts an ongoing relationship into a last period interaction: if one can get seriousiy rich, one can move to Aspen and ski for the rest of one's days. The soft (socially acceptable) NLERS sanctions cannot constrain such behavior and so the law is needed. $^{76}$

But this view of the duty of loyalty poses a puzzle. Given the difficulties for a court in intervening in intrafirm matters, as we detail above, how is it that courts are willing or able to intervene, even in duty of loyalty situations? For basic self-dealing, however inaccurate the court may be, it has little choice. Because of the potential to get seriously rich, only legal or extremely robust nonlegal sanctions (murder, for example) are likely to be sufficient, and the social cost of permitting the robust nonlegal sanctions is too high.

The law also cleverly minimizes the potential for error, however; by narrowly defining the duty of loyalty. Although for agency cost economists stealing and shirking are both agency costs, with the cost to the firm of shirking easily exceeding the cost of stealing, only stealing is considered a violation of the duty of loyalty. Why? There seem to be several reasons. First, stealing is easier to police than shirking because of the availability of market bench marks. Second, shirking can be better controlled by NLERS because there is smaller personal gain to the agent. Third, the greater cost imposed by shirking (combined with the smaller personal gain to the agent) means that product and capital markets will do a better job of punishing shirking than stealing.

But Delaware's approach to the duty of loyalty does more. By providing substantive and procedural incentives to adopt governance

${ }^{76}$ We emphasize that "socially acceptable" NLERS sanctions will be inadequate. As organized crime has demonstrated, sufficiently robust NLERS sanctions may exist to constrain opportunistic behavior. The social cost of such sanctions rightly leads the law to intervene and prevent their use. But, by so doing, the law likewise creates a gap in NLERS self-governance. 
structures that approximate an arm's-length transaction, Delaware harnesses the mechanisms of NLERS governance to reduce the necessity of judicial intervention. Thus, for example, Delaware doctrine emphasizes the role of disinterested directors in self-interested transactions involving board members and the use of special committees in management buyouts and parentesuobsidiany mergers. The effect is tô shift the focus from actors whose self-interest is too large to be constrained by NLERS (the managers or the controlling shareholder) to the independent directors whose self-interest is sufficiently attenuated to make them subject to the softer NLERS sanctions. ${ }^{78}$ The end result is to strengthen the primacy of NLERS governance.

Finally, the extreme standard of liability for waste provides further evidence of Delaware's narrow definition of the duty of loyalty. Under Delaware law, "waste entails an exchange of corporate assets for consideration so disproportionately small as to lie beyond the range at which any reasonable person might be willing to trade." ${ }^{\text {,99 }}$ This standard is probably best understood as providing a theoretical backstop to the protections against fraud and self-dealing. Waste cases typically arise in connection with the transfer of corporate assets falling outside basic self-dealing but which allegedly serve no corporate purpose, or for which no consideration at all is received. Under the waste standard, "[i]f... there is any substantial consideration received by the corporation, and if there is a good faith judgment that in the circumstances the transaction is worthwhile, there should be no finding of waste, even if the fact finder would conclude ex post that the transaction was unreasonably risky." " Thus, cases meeting the waste standard may well be a null set: "But rarest of all-and indeed, like Nessie, possibly non-existent-would be the case of disinterested business people making non-fraudulent deals (non-negligently) that meet the legal standard of waste!"11

\section{The Duty of CARE AND THE BUSINESS JUDGMENT RULE}

The duty of care is less straightforward and more interesting.

"S Se, r.g., Kahn v. Lynch Communication Sys., Inc., 638 A.2d 1110 (Del. 1994).

i* See generally Edward B. Rock, Saints and Sinners: How Does Delaware Corporate Law W'ark?, 4 UCLA L. REV. 1009 (1997).

"Lewis v. Yogelstein, 699 A.2d 327, 336 (Del. Ch. 1997) (citing Grobow v. Perot, 539 A.2d 180, 189 (Del. 1988), and Saxe v. Brady, 184 A.2d 602, 610 (Del. Ch. 1962)).

it $I$.

"Steiner v. Meyerson, No. CV.A. 13139, 1995 WL 441999, at *5 (Del. Ch. July 19, 1995). 
There is a puzzle lying at the heart of modern corporate law that our approach can help resolve. The director's duty of care looks just like a negligence standard. In the typical formulation, the director is expected to perform her functions "with the care that an ordinarily prudent person would reasonably be expected to exercise in a like posi-

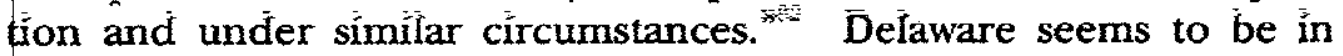
accord: "directors of a corporation in managing the corporate affairs are bound to use that amount of care which ordinarily careful and prudent men would use in similar circumstances. ${ }^{983}$ The Revised Model Business Corporation Act is also similar: "[a] director shall discharge his duties as a director ... with the care an ordinarily prudent person in a like position would exercise under similar circumstances." ${ }^{*{ }^{* 3}}$

Appearances, however, can be deceiving. Several mysteries surround the duty of care. First, the instances in which a court has held a director liable for a breach of the duty of care are vanishingly few. Liability is rarely imposed for a breach of the duty of care unaccompanied by a breach of the duty of loyalty. There are large areas of corporate conduct in which numerous mistakes are undoubtedly made but are simply never the subject of liability. As Dooley and Veasey put it:

[T] he degree of deference accorded board decisions exceeds even the generous boundaries of the business judgment rule in the sense that whole categories of business decisions are simply not reviewable. It is hard to find reported examples of these "nonreviewable" decisions precisely because it is so well understood that they cannot profitably be made the subject of lawsuits. A dividend may be illegal because it exceeds the amount permissible under the statute, but we have no concept of a "negligent" dividend policy even though hindsight indicates that a different allocation between retention and payout of earnings may have been wiser. Similarly, courts will not entertain stockholder complaints that the board should have directed management to devote more effort to research and development or to manufacture this, rather than that, product or that $X$ would have made a better chief financial officer than $Y$. As an instrument of director accountability, the duty of care is neither comprehensive nor particularly well targeted.

The most prominent illustration of this stunning absence is the failed merger. Some people keep personal lists of the worst mergers

82 AM. LAW INST., PRR CIPLES OF CORPORATE GOVERNANCE \$ 4.01(a) (1994) [hereinafter PRINCIPLES OF CORPORATE GOVERNANCE].

${ }_{83}$ Graham v. Allis-Chalmers Mfg, Co., 188 A.2d 125, 130 (Del. 1963).

84 REVISED MODEL BUS. CORP. ACT \& 8.30(a) (2) (1983).

${ }^{85}$ Dooley \& Veasey, supra note 66 , at 520-21 (footnotes omitted). 
ever. Ours would include Pennsylvania Railroad/New York Central, AT\&T/NCR, and Exxon/Reliance Electric. Each involved blunders that cost shareholders billions of dollars. The striking fact to be explained is that these disastrous mergers did not seem to give rise to duty of care suits. If the chance of recovering were even one percent, the expected value of a $\$ 10$ billion case would be $\$ 100$ million.

There are numerous other illustrations. Consider, for example, the implementation of a computer manufacturing system that is so badly managed as to cause an otherwise solid company to reach the brink of bankruptcy (as with Pillowtex ${ }^{86}$ ) or to cause a leading confectioner to miss the key Halloween season (as with Hershey Foods ${ }^{87}$ ). Poorly understood investments in complex hedging strategies that backfire provide another example. Finally, consider the (lack of) liability of directors of bankrupt firms. In the United States, creditors rarely can recover against directors for breach of the duty of care, despite the fact that bankruptcy provides at least a prima facie case for negligence or gross negligence.

Second, the duty of care is a remarkably late addition to Delaware law. In an extremely important article, Henry Horsey, formerly of the Delaware Supreme Court, shows that the first Delaware case to recognize a duty of care is the 1963 case of Graham v. Allis-Chalmers. ${ }^{83}$ There are no additional cases until the 1970s. The first case to impose liability under the duty of care is Smith v. Van Gorkom, decided in 1985. Since then, there have not been any others.

If the duty of care is, in fact, a negligence rule, how come we rarely see cases and almost never see liability in these instances? Why does it come so late? If, despite its appearance, it is not a negligence rule, what is it? ${ }^{89}$ Why does the standard of liability applied to corpo-

${ }^{\text {"t }}$ Stella M. Hopkins, Pillowtex Tries To Fix Problems One by One, HERAID-SUN (Durham, N.C.), Nov. 21, 1999, at B9.

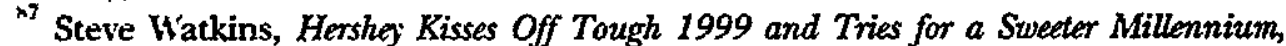
INIESTOR'S BUS. DAIIY, Aug. 10, 2000, at Al.

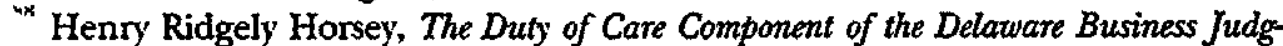
ment Rule, 19 DEL.J. CORP. L. 971 (1994).

"Dooley captures the puzzle well:

We are left with one of two possible explanations for this dichotomy between rhetoric and results: for over one hundred years (1) American judges have intended their articulation of the duty of care to be mostly hortatory or (2) American businesses have been managed with a degree of care and skill unknown in any other human endeavor in the history of the world.

The scarcity of liability judgments implies that the business judgment rule has been an effective shield over the years.

MICHAEL P. DOOLEY, FUNDAMENTALS OF CORPORATION LAW 266 (1995). 
rate directors seem to be so much different from that applied, for example, to doctors and lawyers? Why does directorial malpractice seem so different from legal or medical rnalpractice?

The GHM model of the firm provides the basis for an explanation Recall that in these models transactions are hrought within the firm because governance by contract is insufficient. The choice to bring the transactions into the firm is thus understood as a choice of governance mechanism. From this perspective, the implementation of Delaware's duty of care acts as a jurisdictional device, protecting centralized management and ensuring that the duty of care remains an NLERS. In so doing, it protects the (nonlegal) governance mechanism chosen by bringing activities within the firm.

The two principal modes of implementing the duty of care assume prominence in this context: the business judgment rule and the "sustained inattention to duty" standard in oversight cases. Each plays a somewhat different role and will be considered in order.

From this perspective, the business judgment rule looks very much like, and seems to play the same role as, the employment-at-will doctrine in employment law: it is a rule of judicial nonintervention. Under the employment-at-will doctrine, an employer may discharge an employee for good reason, bad reason, or no reason at all. Put differently, the courts refuse to rule on the reasons for discharge, leaving the conflict to the parties to resolve. Similariy, in the corporate context, the actual standard of review applied by courts to corporate decisionmaking can generally be described as no liability for negligent decisionmaking absent fraud, illegality, or conflict of interest.

Understood this way, the business judgment rule serves to prevent noncontrolling shareholders from complaining to a third party about the business decisions of the central managers. This is important for the reasons discussed earlier. If, as the TCE models of the firm suggest, the decision to bring the activity into the firm is the choice to protect relationships by NLERS, then intervention by third parties interferes with this choice. Moreover, the ability to appeal to a third party provides a tool that can be used strategically by noncontrolling

${ }^{90}$ This, of course, was the claim of Joseph Bishop's classic article thirty years ago. Joseph W. Bishop, Jr., Sitting Ducks and Decoy Ducks: New Trends in the Indemnification of Conporate Officers and Directors, 77 YALE L.J. 1078, 1099 (1968) ("The search for cases in which directors of industrial corporations have been held liable in derivative suits for negligence uncomplicated by self-dealing is a search for a very small number of needles in a very large haystack."). But it remains largely true today, even with, or perhaps as demonstrated by, exceptional cases like Smith $v$. Van Gorkom, discussed infra in Part IV.C. 
shareholders. Finally, the ability to appeal to a third party undermines the self-governing quality of the relationship. Thus, the business judgment rule is about maintaining centralized management, preventing minority opportunism, and preserving NLERS governance.

As in the employment-at-will context, one should not confuse the

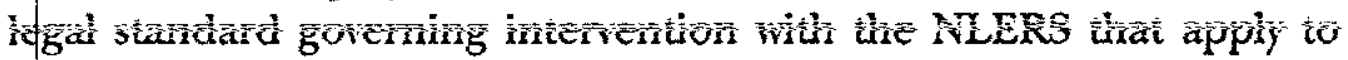
the conduct in question. In the employment context, while the legal standard is that courts will not intervene in discharges unless the discharged employee can come within the narrow "public policy" exception, no one thinks that the standard governing conduct within (nonunion) firms is generally to fire people for bad reasons or no reasons. Similarly, as we discuss in more detail below, the laxness of the legal standard of review of business decisions should not be confused with the NLERS that governs management decisionmaking."1

The traditional implementation of the business judgment rule is entirely consistent with this analysis. In the older cases, courts said that they: "will not step in and interfere with honest business judgment of the directors unless there is a showing of fraud, illegality or conflict of interest."'12 This is a pure statement of what we are calling a jurisdictional rule and is precisely what the TCE models would predíct.

Starting with Graham v. Allis-Chalmers, the Delaware courts began talking in terms of a director's "duty of care." By Aronson v. Lewis in 1984, the Delaware Supreme Court started to emphasize negligence concepts and described the business judgment rule as protecting business judgments absent "gross negligence.",

This shift in the articulation of the business judgment rule, or perhaps its transformation, came to prominence with Smith $v$. Van Gorkom, in which the court imposed liability for a grossly negligent decision on a merger proposal. ${ }^{9.5}$ Although we will discuss the case in more detail below, ${ }^{36}$ at this point it is worth noting that under the older "absent fraud, illegality or conflict of interest" articulation of the

") Sir discussion infra in Part IV.

Shlensky v. Wrigley, 237 N.E.2d 776, 778 (Ill. App. Ct. 1968); see also Kamin v. Am. Express Co., 383 N.Y.S.2d 807, 810 (N.Y. Sup. Ct) ("Courts will not interfere with such discretion unless it be first made to appear that the directors have acted or are ahout to act in bad faith and for a dishonest purpose." (internal quotation omitted)), aff I. 387 N.Y.S.2d 993 (N.Y. App. Div. 1976).

188 A.2d 125 (Del. 1963).

"173 A.2d 805, 812 (Del. 1984).

488 A.2d 858 (Del. 1985).

"Sic discussion infra in Part IV.C. 
business judgment rule, Van Gorkom would have been an easy case. While there was ample evidence of sloppiness and even gross negligence, there was absolutely no evidence at all of fraud, illegality, or conflict of interest.

Interestingly, the legislative response in section 102(b)(7), which allows firms to eliminate monetary liability for nonintentional breaches of the duty of care, largely restored the old rule because the line between intentional and nonintentional breaches of the duty of care largely tracks the line drawn by "fraud, illegality or conflict of interest." Indeed, by doing so, the statutory provision saves the Delaware courts from having to find their way out of the difficulties to which embracing a negligence or gross negligence standard led. The legislative response, however, did not entirely restore the status quo ante, as it would still allow injunctive relief for grossly negligent decisions in cases like Signal and Shlensky $v$. Wrigley.

Melvin Eisenberg, who is also struck by the contrast, offers an explanation that rests on the nature of the decisions made. ${ }^{97}$ The paradigm negligence context, he suggests, typically involves simple decisions in which "there is often little difference between decisions that turn out badly and bad decisions.... In contrast, ... business decisions [are more open ended and risky so that hindsight bias makes it particularly difficult for the decisionmaker] to distinguish between bad decisions and proper decisions that turn out badly." ${ }^{98}$ As Franklin Gevurtz has argued trenchantly in response, however, such a distinction cannot explain the observed differences between professional malpractice in law and medicine and directorial liability. ${ }^{99}$ Medical and legal decisions seem to face precisely the same uncertainty as business decisions, with a balancing of potential for benefit and risks of loss. Moreover, hindsight bias is at least as strong in the medical and legal contexts as in the corporate context. ${ }^{100}$ Yet doctors and law-

${ }^{97}$ Melvin Aron Eisenberg, The Divergence of Standards of Conduct and Standards of Review in Conporate Law, 62 FORDHAM L. REV. 437 (1993).

${ }_{98}$ Melvin Aron Eisenberg, The Director's Duty of Care in Negotiated Dispositions, $51 \mathrm{U}$. MIAMI L. REV. 579, 585 (1997); see also Bayless Manning, The Business Judgment Rule and the Director's Duty of Attention: Time for Reality, 39 Bus. LAW. 1477, 1489-91 (1984).

${ }_{99}$ Franklin A. Gevurtz, The Business Judgment Rule: Meaningless Verbiage or Misguided Notion?, 67 S. CAL. L. REV. 287 (1994), makes this point vigorously and at length; for a treatment of the issue from the medical malpractice perspective, see Hal R. Arkes \& Cindy A. Schipani, Medical Malpractice v. the Business Judgment Rule: Differences in Hindsight Bias, 73 OR. L. REv. 587, 601 (1994).

${ }^{100}$ See Arkes \& Schipani, supra note 99 , for a review of the hindsight bias in medical decisionmaking. 
yers are held liable for malpractice infinitely more often than directors." ${ }^{\text {I'1 }}$

Our NLERS analysis provides an alternative, or perhaps complementary, explanation for the striking difference between the duty of care in corporate law and the negligence standard. The difference ines in the context in which the parties estabilish their relationshìns: corporate decisionmaking is brought within the firm and is governed by NLERS while professional malpractice arises from transactions through the market that typically are and must be law-governed. To unpack this claim, it is useful to proceed in several steps.

First, professional malpractice in particular, and negligence in general, represent the use of legal sanctions to control conduct. NLERS are unlikely to work in the typical negligence context because the interaction among the parties is often one shot, with no opportunity to negotiate terms. In the medical or legal context, while there may be some opportunity to negotiate terms, the difference in knowledge between the professional and the client, the imperfections of the markets, and the likelihood of the potential harm are such that the opportunity to negotiate terms governing liability for malpractice is limited. Moreover, the stakes are sufficiently high that NLERS are unlikely to suffice.

Participants in the firm, as we emphasized earlier, are in a continuous set of interactions. The nature of the relationship between the parties and the presence of specific assets are such that it is in just such cases that NLERS governance is likely to trump law governance. Our argument, then, is that the critical difference between the directorial and the other professional duties of care is not in the nature of the decisions-as Eisenberg suggests-but in the nature of the relationships among the actors.

The oversight cases are similar. As in the case of waste, by setting

${ }^{3 \prime 1}$ Id. at 613-14 ("The similarities between the business person's and the physician's liability standards end with the duty of care standard, however."). Eisenberg also makes an additional argument. Because, he says, there is a great asymmetry between what a director receives and the magnitude of liability for negligent decisions, imposing liability both would be unfair and would discourage good people from becoming difectors. Ser Eisenberg, supra note 97, at 444. But, of course, neurosurgeons, obstetricians, and securities lawyers make precisely the same argument. The fees they receive for an operation, delivery, or public offering are far less than the liability that is inposed when they commit malpractice. Gevurtz, supra note 99, at 314. From the victins' perspective, moreover, there is no lack of proportionality to be explained: in each case, the relevant comparison is between damages imposed and harm suffered. Eipenberg, supra note 98, at 587-89. 
an almost outrageously high standard for liability under the duty of care for nonfeasance, Delaware law protects corporate selfgovernance. Thus, in the casebook favorite, Francis $v$. United Jersey Bank, a New Jersey case, Mrs. Pritchard was utterly and totally passive, overborne by sons who looted the corporation and drove it into bankruptcy ${ }^{102}$ Moreover, by the time the case was brought, because Mrs. Pritchard had already died, the real parties in interest were presumably the heirs to her estate who seem to have been the same despicable sons.

\section{A. An Historic Speculation}

So what is going on here? Why does the "duty of care" appear so late in Delaware jurisprudence? Why does it appear when it does? Once it does appear, why does it appear so grudgingly? Why the incomplete transformation of the legally enforceable duties of directors from loyalty to loyalty and due care?

Here is an hypothesis. Up until the 1960s, the duty of care, in Delaware and elsewhere, was an NLERS: it was almost an entirely nonlegally enforced rule or standard. Then, in the 1960s, people generally lost faith in the effectiveness of NLERS and, across the law, turned to legal enforcement. One can observe this transformation in torts, contracts, products liability, environmental law, constitutional law, antidiscrimination law, and elsewhere. The same transformation affected corporate law: the implicit consensus that had held for a hundred years broke down. The thrust of the Cary critique of Delaware corporate law was that markets and norms could not be trusted to constrain managers sufficiently. ${ }^{103}$ The law needed to intervene. And thus, arguably in response to the general societal shift and the general critique of Delaware's laxness, Delaware started to transform the duty of care from an NLERS to a legal rule. ${ }^{1 / 4}$

Such a move, however, faced a problem. Because of the nature of

${ }^{102} 432$ A.2d 814 (N.J. 1981). According to the opinion, "[a]fter her husband died in December 1973, Mrs. Pritchard became incapacitated and was bedridden for a sixmonth period. She became listless at this time and started to drink rather heavily." Id. at 819 .

${ }^{103}$ Horsey, supra note 88, at 991 .

${ }^{104}$ Interestingly, a legally enforceable duty of care emerged even later in the United Kingdom, with the "beginnings of the modern approach" coming only in 1977 in Dorchester Finance Co. v. Stebbing, "[d] ecided in 1977 but fully reported only in 1989: [1989] BCLC 498." PAUL L. DAVIES, GOWER'S PRINCIPLES OF MODERN COMPANY LAW $641 \&$ n.57 (6th ed. 1997) (second brackets in original). 
the firm, discussed earlier, governance almost has to be by NLERS, or at least works much better when it is. The Delaware judges seemed to have sensed this problem. Thus we get the peculiar incoherence of the transformation of Delaware law. On the one hand, the cases embrace a legally enforceable duty of care that incorporates concepts of

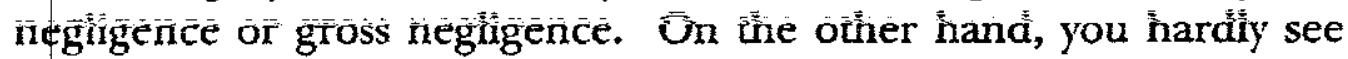
any cases. Smith v. Van Gorkom is the exception, not the rule. Graham v. Allis-Chalmers ${ }^{105}$ and Caremark ${ }^{106}$ both talk in terms of a judicially enforced duty of care but do not impose any liability. Aronson likewise uses negligence language but also does not impose liability. ${ }^{\text {Iv7 }}$

\section{B. Some Illustrative Cases}

If the duty of care is implemented by rules of judicial abstention that make the duty of care an NLERS and thereby protects the integrity of intrafirm governance, then one would predict that duty of care cases would be close to a null set. In fact, of course, they are. There are but a handful of duty of care cases, nearly all of which end up in everyone's corporate law casebook. Yet the number of cases, though small, is not zero. We need to explain how the cases fit into our theory. We claim that the duty of care cases one observes can best be understood as either preserving NLERS governance or as reflecting instances in which NLERS governance predictably breaks down in ways similar to the breakdown observed in the duty of loyalty context.

\section{Kamin v. American Express}

This classic is as pure a duty of care case as one can observe. It revolves around an unsuccessful investment by American Express. ${ }^{105}$ In 1972, American Express acquired for investment shares in Donaldson, Lufkin and Jenrette, Inc. at a cost of around $\$ 30$ million. By 1975 , the shares were only worth around $\$ 4$ million. Having decided to get rid of the shares, the American Express board chose to do so by distributing the shares as a special dividend to shareholders rather than selling them and recognizing the capital loss. It is undisputed that had American Express sold the shares, it would have reduced its federal tax liability by approximately $\$ 8$ million, a benefit that was en-

"1": 188 A.2d 125 (Del. 1963).

I'n. In re Caremark Int'l Inc. Derivative Litig., 698 A.2d 959 (Del. Ch. 1996).

${ }^{1167}$ Aronson v. Lewis, 473 A.2d 805 (Del. 1984).

lus Kamin v. Am. Express Co., 383 N.Y.S.2d 807 (N.Y. Sup. Ct.), affd, 387 N.Y.S.2d 993 (N.Y. App. Div. 1976). 
tirely foregone by distributing the shares in kind to shareholders. Shareholders challenged the decision as a breach of the duty of care and waste. In an application of the business judgment rule, the court dismissed the case on summary judgment.

The fun of teaching the case is exploring with the students whether the decision was the right one or the wrong one, and, if wrong, how wrong. The board's explanation that they were acting in shareholders' interests by keeping reported earnings high typically impresses the students. This provides an opportunity to explore the extent to which one must suppose the stock market to be informationally inefficient in order for this argument to make sense.

The case stimulates every bit as interesting a discussion with general counsels, CEOs, private equity investors, and directors. Among these groups, there is a much greater appreciation of how problematic the board's decision was, namely, the decision to forego $\$ 8$ million in cash in hand in order to dress up reported earnings. Interestingly, among this group, people sometimes say that while, if it had been their own money, they would never have made this choice, it might be plausible in a publicly traded corporation. Also, some people say that while such a choice may have been plausible in the $1970 \mathrm{~s}$, today it would not be, because the market has become more sophisticated in seeing through such strategems.

On our analysis, the case was decided correctly. While the deci= sion, even in the 1970s, was probably a pretty dumb one, it was an absolutely typical business decision. As such, absent a showing of selfdealing, the court was right to stay out. ${ }^{109}$ This is not to say that such dumb decisions go unpunished. On the contrary, the full range of nonlegal sanctions apply if, in fact, most people in the business world would view the decision as dumb. The market price of the stock might take a hit, directors might be embarrassed by the decision, analysts and financial columnists might criticize it, and so forth.

\section{Caremark}

While Kamin is a classic business decision case, the Caremark case

${ }^{109}$ There was a plausible self-dealing claim alleged in the briefs but not the complaint that the insider directors influenced American Express to distribute rather than sell the shares in order to overstate earnings and thereby increased their incentive compensation, which was tied to reported earnings. The court dismissed the argument because the argument was "highly speculative" and there was no showing that the insiders dominated the board. In fact, of course, the argument was quite plausible and may well have been the actual explanation. 
raises a classic director oversight issue. ${ }^{110}$ On its face, it might seem to provide a problem for our theory. Caremark involved a settlement of a derivative suit alleging that the board of Caremark had breached its duty of care by failing to be adequately informed. Had it been adequately informed, the plaintiffs claimed, the board would have de-

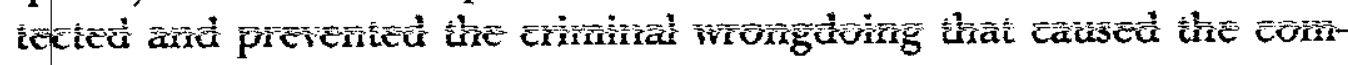
pany millions of dollars of losses.

In the context of approving the settlement, Chancellor Allen had occasion to review Delaware case law in the area, particularly Graham v. Allis-Chalmers." In that case, the Delaware Supreme Court held that the board's lack of awareness of criminal price fixing by employees did not violate the duty of care.

In reviewing Graham, the court pointed out that the Federal Sentencing Guidelines fundamentally changed the world by imposing substantially higher penalties on corporations without internal compliance programs if an employee is found to have violated the law. Post-Sentencing Guidelines, does the duty of care require that the board adopt an adequate internal compliance program?

Perhaps. Chancellor Allen expressed the following view of Delaware law:

In light of these developments, it would, in my opinion, be a mistake to conclude that our Supreme Court's statement in Graham concerning "espionage" means that corporate boards may satisfy their obligation to be reasonably informed concerning the corporation, without assuring themselves that information and reporting systems exist in the organization that are reasonably designed to provide to senior management and to the board itself timely, accurate information sufficient to allow management and the board, each within its scope, to reach informed judgments concerning both the corporation's compliance with law and its business performance.

Obviously the level of detail that is appropriate for such an information system is a question of business judgment. And obviously too, no rationally designed information and reporting system will remove the possibility that the corporation will violate laws or regulations, or that senior officers or directors may nevertheless sometimes be misled or otherwise fail reasonably to detect acts material to the corporation's compliance with the law. But it is important that the board exercise a good faith judgment that the corporation's information and reporting system is in concept and design adequate to assure the board that appropriate information will come to its attention in a timely manner as a matter of

"In 698 A.2d 959 (Del. Ch. 1996).

"I88 A.2d 125 (Del. 1963). 
ordinary operations, so that it may satisfy its responsibility.

Thus, I am of the view that a director's obligation includes a duty to attempt in good faith to assure that a corporate information and reporting system, which the board concludes is adequate, exists, and that failure to do so under some circumstances may, in theory at least, render a

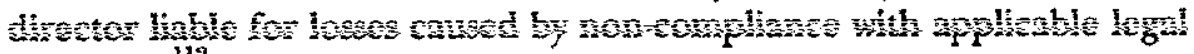
standards.

In applying this standard to the proposed settlement, the court found that the plaintiffs' claim was very weak because "the corporation's information systems appear to have represented a good faith attempt to be informed of relevant facts." 113 As in other settlements, the weakness of the plaintiffs' claim becomes support for approving even a modest benefit for shareholders.

The Caremark opinion has been widely read by practitioners as requiring that boards adopt internal compliance programs in order to satisfy the duty of care. ${ }^{114}$ The potential conflict for our theory is that the court in Caremark seems to be at least nudging firms towards adopting explicit internal compliance programs to prevent criminal wrongdoing. On our theory, one might think this anomalous, as we do not observe courts telling firms to adopt particular types of inventory controls, ordering protocols, information technology standards, or any number of other complex internal control mechanisms.

The conflict, however, may be more apparent than real. There are two possibilities. First, Caremark may not really be a duty of care case at all. It may be better understood as a case involving the duty to act lawfully, an area that traditionally has fallen outside of the business judgment rule. Because of public policy imperatives, obeying the law has traditionally been considered a boundary condition within which firms maximize profits, but not, itself, subject to that calculus. This is the thrust of the middle exclusion in the traditional formulations of the business judgment rule, "absent fraud, illegality or conflict of interest."

112 Caremark, 698 A.2d at 970 (footnote omitted).

113 Id. at 971.

114 See, e.g., Edward Brodsky, Directors' Liability-Importance of Compliance Procedures, N.Y. L.J., Feb. 13, 1997, at 3 (discussing the broader effects of Caremark's essential requirement that directors must implement compliance programs); Michael G. Radigan, Standards for Corporate Compliance Programs: Counsel Should Be Aware of Seven Basic Considerations, N.Y. L.]., Sept 8, 1997, at S4 ("[Caremark] underscores the importance of maintaining an effective corporate compliance program...."). For a case giving Gra. ham more current vitality, see In re Baxter International, Inc. Shareholders Litigation, 654 A.2d 1268 (Del. Ch. 1995). 
As such, Caremark may be the corporate governance analog to the "public policy" exception to the employment-at-will doctrine. That exception holds that while you may discharge an employee for good reason, bad reason, or no reason at all, you may not discharge an employee for a reason that violates public policy (narrowly defined), such

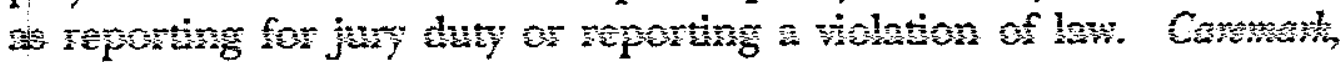
like these cases, may thus be nothing more thańn a narrow exception to the deference to private ordering driven by an overarching public policy imperative. ${ }^{115}$ Whether Caremark represents a significant change, or just a narrow exception or less, must await its treatment in future opinions.

A second possibility is that the actual standard articulated in Caremark in fact supports our theory. After finding that the Caremark board acted reasonably, Chancellor Allen suggested the standard for liability, a standard much less demanding than that suggested by the language quoted above:

Generally where a claim of directorial liability for corporate loss is predicated upon ignorance of liability creating activities within the corporation, as in Graham or in this case, in my opinion only a sustained or systematic failure of the board to exercise oversight-such as an utter failure to attempt to assure a reasonable information and reporting system exits [sic]-will establish the lack of good faith that is a necessary condition to liability. Such a test of liability-lack of good faith as evidenced by sustained or systematic failure of a director to exercise reasonable oversight-is quite high.

One can thus read Caremark to require only that directors face the monitoring question before they adopt any particular type of system or decide against adopting any system at all.

Supporting this interpretation are the facts of the case. To Chancellor Allen, the efforts of the Caremark directors in monitoring the activities of the firm's senior executives were exemplary, if for no other reason than they kept trying. We are told that Caremark first developed a "Guide to Contractual Relationships" in 1989, recognizing however that "there was uncertainty concerning Caremark's interpretation of the law."177 Apparently, this guide was either not followed or instructed executives to take actions that subsequently turned out to be unlawful. By 1992, in the face of a massive investigation into its

"Bill Sage has suggested that Caremark may be limited to the heavily regulated health care sector.

tt. Carmark, 698 A.2d at 971 .

"I7 Id. at 962. 
referral payments to doctors, alleged to be "kickbacks" by the U.S. Department of Health and Human Services ("HHS"), Caremark was still asserting "that its management, pursuant to advice, did not believe that [their referral practices] were illegal. ${ }^{\text {,118 }}$ By the fourth edition of the Guide, issued later in 1992, Caremark finally made changes that were apparenuly ảesigne complied with the [rules] or excluded [patients covered by the rules] altogether."119 Clearly the HHS rules were unclear. What is the content of the monitoring obligations when guidelines are vague? The practices adopted in the Guide pushed the envelope on what might be considered lawful, and they apparently pushed it too far. To the extent that the directors monitored and approved the Guide, their contribution was to increase the company's risk exposure. Yet, even in this case, because the board did not show sustained inattention, the likelihood of the plaintiffs prevailing on the merits was deemed to be small by the Chancellor.

\section{Ovitz/Disney}

The most interesting recent case for our approach is the litigation arising out of Michael Ovitz's departure from Disney. ${ }^{120}$ In 1995, Ovitz, one of the great Hollywood agents, was hired to be the number two person at Walt Disney Co. A year later, Ovitz was out, with a severance package based on his original compensation agreement worth approximately $\$ 140$ million.

In the wake of Ovitz's departure, Graef Crystal, the prominent corporate compensation consultant who assisted the board in structuring the compensation package at the time Ovitz was hired, was quoted as saying: "Of course, the overall costs of the package would go up sharply in the event of Ovitz's termination (and I wish now that I'd made a spreadsheet showing just what the deal would total if Ovitz had been fired at any time). ${ }^{121}$ Crystal subsequently was mentioned in an article that appeared in the January 13, 1997, edition of California Law Business. "With no one expecting failure, the sleeper clauses in Ovitz's contract seemed innocuous, Crystal says, explaining that no one

118 Id.

119 Id.

${ }^{120}$ In re Walt Disney Co. Derivative Litig., 731 A.2d 342 (Del. Ch. 1998), affd in part, rev'd in part sub nom. Brehm v. Eisner, 746 A.2d 244 (Del. 2000).

121 Graef Crystal, Mike Ovitz Got Away with Murder... and I Helped Him, SLATE, Dec. 21, 1996 (emphasis added), at http://www.slate.msn.com/Features/MikeOvitz/ MikeOvitz.asp. 
added up the total cost of the severance package."122 As the court explained in subsequent litigation, "[t]he article then quotes Crystal as saying that the amount of Ovitz' severance was 'shocking' and that "nobod! quantified this and I wish we had."'123

In the wake of Ovitz's departure, a plaintiff brought a derivative

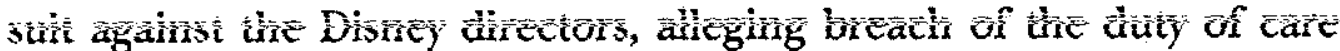
and waste. "The Delaware Court of Chancery viewed the case as raising the same issues as a board decision to authorize a loan, with no special concerns or review triggered by the sheer size of the severance. Using a straightforward demand analysis under the two-prong A romsm test, Chancellor Chandler held that plaintiffs "have not raised a reasonable doubt as to the absence of self-interest of any of the directors in approving or honoring the Employment Agreement," first prong of the test. Plaintiffs likewise failed to "create a reasonable doubt that the Board's decisions to approve the Employment Agreement or to grant Ovitz a Non-Fault Termination were a product of the Board's business judgment," the second prong of the Aronson test. ${ }^{127}$ Accordingly, Chancellor Chandler granted the motion to dismiss.

Chancellor Chandler's opinion is precisely what our positive theory would predict. Compensation contracts, especially for new employees, are just like a host of other contracts with third parties and are the paradigm of day-to-day business decisions. Like the Kamin case, however ill-advised the original compensation agreement wasand one never gets admissions like those of Graef Crystal-our theory would predict that the court would stay out, leaving the matter to the array of nonlegal sanctions.

More problematic for our theory is the Delaware Supreme Court opinion on appeal. In an opinion somewhat reminiscent of Caremark, the Delaware Supreme Court, per Chief Justice Veasey, took the Disney board to task for bad corporate governance practices. What, for Chancellor Chandler, was an easy case, for the supreme court was:

potentially a very troubling case on the merits. On the one hand, it appears from the Complaint that: (a) the compensation and termination payout for Ovitz were exceedingly lucrative, if not luxurious, compared to Ovitz' value to the Company; and (b) the processes of the boards of

1... Garry Abrams, Paying Bills, Cal. L. Bus., Jan. 13, 1997, at 12, 13.

$1.3 \mathrm{Br} / \mathrm{hm}, 746 \mathrm{~A} .2 \mathrm{~d}$ at 251 (quoting Abrams, supra note 122, at 13).

lit In r. Walt Disney Co. Derivative Litig., 731 A.2d 342.

ini $l d$. at 350 .

I." Id. at 361 .

1.7 Id. at 365 . 
directors in dealing with the approval and termination of the Ovitz Employment Agreement were casual, if not sloppy and perfunctory. On the other hand, the Complaint is so inartfully drafted that it was properly dismissed under our pleading standards for derivative suits. From what we can ferret out of this deficient pleading, the processes of the Old Board and the New Board were hardly paradigms of good corporate governance practices. Moreover, the sheer size of the payout to Ơtitz, as alleged, pushes the envelope of judicial respect for the business judgment of directors in making compensation decisions. Therefore, both as to the processes of the two Boards and the waste test, this is a close case.

Although the Delaware Supreme Court ultimately affirmed the dismissal, with the exception of allowing the plaintiffs a narrow opportunity to replead, the court heaped substantial criticism on the board's performance. ${ }^{129}$ On the first prong of the Aronson test-board independence-the supreme court affirmed the chancery court without reservation. ${ }^{130}$

Things get interesting when the supreme court turns to the second prong, namely, whether plaintiffs had created a reasonable doubt that the decision was subject to the business judgment rule. In their appeal, the plaintiffs claimed that the chancery court had erred when it concluded that a board of directors is "not required to be informed of every fact, but rather is required to be reasonably informed." ".,3 The supreme court, characterizing the Chancellor's formulation as "too cryptically stated," provided its own formulation, emphasizing negligence concepts:

Pre-suit demand will be excused in a derivative suit only if the Court of Chancery in the first instance, and this Court in its de novo review, conclude that the particularized facts in the complaint create a reasonable doubt that the informational component of the directors' decisionmaking process, measured by concepts of gross negligence, included consideration of all material information reasonably available.

On its face, this seems like a real (that is, legally enforced) negligence standard under which one would expect the plaintiffs to win and, thus, is potentially inconsistent with our understanding of the

${ }^{128}$ Brehm, 746 A.2d at 249.

${ }^{129}$ See id. at 267. The opinion also "clarified" that a chancery court ruling that demand is futile is to be reviewed on a de novo standard, despite language in Aronson that suggested otherwise. Id. at 253-54.

${ }_{130}$ Id. at $256-58$.

131 Brehm, 746 A.2d at 258 (quoting In re Walt Disney Co. Derivative Litig.. 731 A.2d at 362).

${ }^{132}$ Id. at 259 (citation omitted). 
duty of care. After all, given Crystal's testimony, there is a decent case that no one calculated the cost of the severance package if Ovitz were terminated after a year. Moreover, the amounts at issue arguably are material, especially in the context of compensation. The failure of the board to consider all material information reasonably available thus

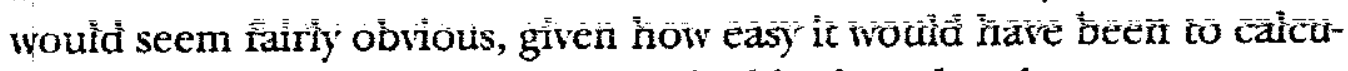
late the cost of severance, if anyone had bothered to do so.

If the supreme court took this approach, it would seem to pose a problem for our analysis as it would make the duty of care look very much like a negligence rule. Because the court read the complaint as alleging that no one calculated the amount of the severance packagc, not Crystal and not the board, the supreme court rejected the chancery court's analysis as "inappropriately simplistic at the pleading stage to state a comprehensive analysis of the issue." ${ }^{\text {133 }}$ The court then provided the plaintiffs with an opportunity to replead to establish that the board had not reasonably relied on Crystal as an expert. What do we make of the case?

There are a couple of responses. First, if one examines what the supreme court did, rather than what it said, it largely is consistent with our approach. Although there was a strong basis for alleging negligence, the court nonetheless dismissed the case, simply allowing the plaintiff to replead without prejudice. Second, one might view this as a classic hortatory opinion, seeking to push boards towards better corporate governance practices without imposing liability, a genre of Delaware case that Rock explores more extensively in Saints and Sinners. ${ }^{1.12}$ We discuss the connection between this type of opinion and norm self-governance below in Part V.

Here, as in the waste context, the standard remains exceedingly undemanding, despite the (possibly inconsistent) hortatory tone of the opinion. If the case were to be repleaded, the likelihood of it surviving a motion to dismiss would be exceedingly low. The Chief Justice already hints at the basis for sustaining the business judgment rule presumption:

The Complaint, fairly construed, admits that the directors were advised by Crystal as an expert and that they relied on his expertise.... The [Chancery'] Court's invocation here of the concept of the protection accorded directors who rely on experts... is on the right track, but the 
Court's analysis is unclear and incomplete. ${ }^{135}$

In other words, if repleaded, the case would likely fail because Disney reasonably relied in good faith on qualified experts (Crystal!). Even if the experts' calculations were badly off mark, Disney's directors are protected under Delaware Ceneral Corporation Law section 141 (e) if they reasonably relied in good faith on them.

\section{The Courts' Reluctance To Enjoin Dumb Decisions}

Another persistent feature of corporate law is the courts' reluctance to second-guess ill-advised management decisions even prospectively when the issue is enjoining an apparently foolish decision. In these cases, there is no concern that imposing monetary liability on directors will discourage competent people from serving. Were the duty of care a negligence rule, one might expect that courts would be willing to intervene to prevent negligence from occurring.

Here, the classic case is Shlensky $v$. Wrigley. ${ }^{136}$ Shareholders challenged Wrigley's refusal to install lights to allow the Chicago Cubs to play night games at Wrigley field. Plaintiffs submitted evidence that while weekend attendance figures were similar for White Sox and Cubs games, the Sox drew substantially more fans to their weeknight games than the Cubs drew to their weekday games. The plaintiffs further alleged that Wrigley's refusal flowed from his concern about the impact of night games on the surrounding neighborhood. The court dismissed the complaint, holding that absent a showing of "fraud, illegality or conflict of interest, ${ }^{, 137}$ it would not intervene.

Gimbel v. Signal Cos. is a somewhat similar case. ${ }^{138}$ In that case, plaintiffs sought an injunction against the decision by the Signal board to sell its wholly owned subsidiary, Burmah Oil. According to the plaintiffs, the $\$ 480$ million purchase price was wholly inadequate. Moreover, the plaintiffs argued that it was the product of a thoroughly inadequate board process. The managers negotiated the transaction and could have presented it to the board in a way that allowed timely consideration. Rather than do so, they held it back, only springing it on the board at the last minute and receiving a "rubber stamp" approval. ${ }^{139}$

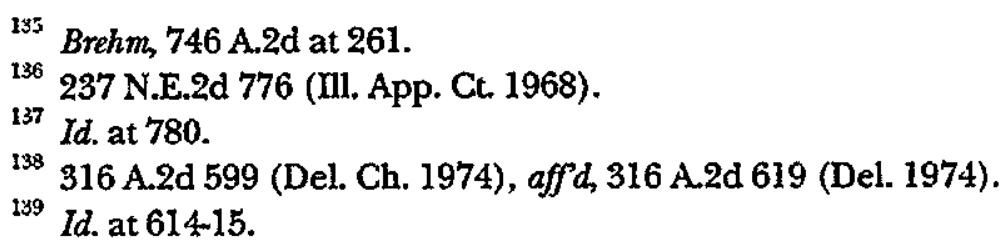


Chancellor Quillen was perturbed by the manner in which the decision was made. Management evidently intended to recommend a sale as early as October. Although there was a regularly scheduled board meeting in late November with $100 \%$ attendance, and although the board of the subsidiary had already been informed so as to quiet

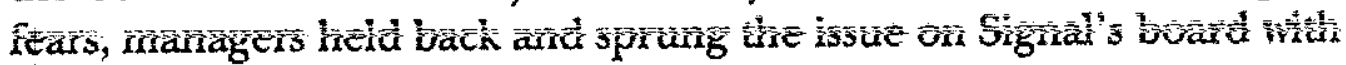
only two days notice and without any advance notice of the subject matter. The hastiness of the method, combined with a price that arguably was shockingly low, led the court to conclude that:

plaintiff would have a reasonable prospect of success on the merits since limited record indicates a gross disparity between the fair market value of Signal Oil on December 21, 1973 and what the Board of Directors were willing to sell the company for, namely, $\$ 480,000,000$. To the extent the scale tips, on the present record, the nod is to the plaintiff. But I hasten to add that an extremely high security consistent with the figures being discussed, should be required. ${ }^{140}$

The court then granted an injunction conditional on the plaintiffs' posting a $\$ 25$ million bond. The plaintiffs, unable and unwilling to post such a bond, appealed to the Delaware Supreme Court. The court affirmed the Chancellor and refused to grant the plaintiffs' demand for a "hold separate" order that would hold the two firms separate in order to enable rescission if ultimately ordered.

This is an odd case. By conditioning the injunction on the posting of an impossibly high bond, the court was either engaging in hortatory rhetoric (which we discuss further below) or calling the plaintiffs' bluff. If the plaintiffs were right that the deal was a bad deal, they should have been able to find someone to post the bond. Either way, the opinion is odd, although it introduces Delaware readers to how the gang at Signal operates, the same gang that returned to center court a few years later in Weinberger $v$. UOP, Inc. ${ }^{141}$ Unlike Signal, the plaintiffs win in Weinberger because of the conflict of interest between parent and partly owned sub that permits legal intervention against the same bad governance practices.

\section{Cede E̊ Co. v. Technicolor, Inc.}

Finally, interesting light is cast when we turn to the complex and problematic set of opinions growing out of the dispute between Cinerama and Ronald Perelman over Perelman's acquisition of the 
Technicolor Corporation. ${ }^{142}$ In addition to raising a variety of other interesting issues, the litigation starkly posed the question whether the duty of care is to be understood as a type of negligence rule.

The litigation arose out of a fairly standard, if early, leveraged buyout. In 1982, Ronald Perelman, through MacAndrews and Forbes Group, Inc., his acquisition vehicle, entered into negotiations to acquire Technicolor, a company in which he had no previous financial stake. Negotiating with the board and Technicolor's investment bankers, Perelman ultimately agreed to buy Technicolor for $\$ 23$ per share. He launched a tender offer at that price, into which over $82 \%$ of the shareholders tendered, and shortly thereafter completed his acquisition with a freeze-out merger at the same price, with $89 \%$ voting to approve the merger.

Cinerama, which owned $4.4 \%$ of Technicolor, opposed the transaction, did not tender, and dissented from the merger. Cinerama then commenced an appraisal action and, subsequently, brought a separate action against the Technicolor directors alleging breach of fiduciary duties and seeking substantial damages. According to Cinerama, a majority of the Technicolor directors faced disabling conflicts of interest.

In the first round of the litigation, Chancellor Allen held that while discovery in the cases could proceed in parallel, Cinerama would eventually have to elect one action or the other. This holding was reversed by the Delaware Supreme Court, which held that Cinerama could pursue both cases concurrently, through trial. ${ }^{143}$

On remand, the chancery court conducted a forty-seven-day trial in which issues of valuation (the appraisal action) and issues of fiduciary duty (the personal liability action) were both litigated. ${ }^{1+4}$ After trial, the court held, in the appraisal action, that the fair value of Cinerama's shares at the time of the merger was $\$ 21.60$ per share, substantially less than the price that Perelman paid. ${ }^{145}$

In the personal liability action, Chancellor Allen held that at least seven of the nine Technicolor directors were disinterested and, moreover, were not at all dominated by the two directors who argua-

${ }^{142}$ See Cede \& Co. v. Technicolor, Inc., 542 A.2d 1182 (Del. 1988) (Cede I); Cede \& Co. v. Technicolor, Inc., 634 A.2d 345 (Del. 1993) (Cede II); Cinerama, Inc. v. Technicolor, Inc., No. 8358, 1991 Del. Ch. LEXIS 105 (June 21, 1991).

${ }^{143}$ Cede 1,542 A.2d at $1188-89$.

${ }^{144}$ See Cinerama, 1991 Del. Ch. LEXIS 105, at *6.

${ }^{145}$ See Cede \& Co. v. Technicolor, Inc., No. 7129, 1990 Del. Ch. LEXIS 259, at *107 (Oct. 19, 1990). 
bly were interested. But, although he held that a majority of the board was disinterested, he accepted, for purposes of the opinion, that they may have acted negligently in failing to inform themselves adequately of alternatives to Perelman's offer. At least judged by subsequently announced standards, Allen suggests that the Technicolor board may not have conducted an adequate "market test."

This assumption sets up the interesting question in the case. Does the fact that the board may have acted negligently in selling the company by itself shift the standard of review from the business judgment rule to the entire fairness test? And, if so, do the defendant directors bear the burden of establishing that the transaction was entirely fair to the corporation, against the second-guessing of the plaintiffs?

Chancellor Allen answered the question in the negative:

I make these assumptions freely because they highlight what I view to be a fatal weakness in plaintiff's case. It is not the case, in my opinion, that in an arm's-length, third party merger proof of a breach of the board's duty of due care itself entitles plaintiff to judgment. Rather, in such a case, as in any case in which the gist of the claim is negligence, plaintiff bears the burden to establish that the negligence shorm was the proximate cause of some injury to it and what that injury was. ${ }^{1: 6}$

Allen, after elaborating on and quoting Learned Hand's opinion in Barmes $v$. Andrews, ${ }^{117}$ went on to hold that:

\footnotetext{
13. Id. at $* 56-* 57$ (citations omitted).

117 Chancellor Allen wrote that:
}

In Barnes v. Andrews, then District Judge Learned Hand addressed the liability of a corporate director whom he found to have been negligent, "though his integrity was unquestioned." The suit was brought by the receiver of a corporation that had been ruined by mismanagement and waste. The court denied a judgment to the plaintiff despite the determination of negligence by the director-defendant:

This cause of action rests upon a tort, as much though it be a tort of omission as though it had rested upon a positive act. The plaintiff must accept the burden of showing that the performance of the defendant's duties would have aroided loss, and what loss it would have avoided.

$* * *$

But when a business fails from general mismanagement, business incapacity, or bad judgment, how is it possible to say that a single director could have made the company successful, or how much in dollars he could have saved? Before this cause can go to a master, the plaintiff must show that, had Andrew's done his full duty, he could have made the company prosper, or at least could have broken its fall. He must show what sum he could have saved the company. Neither of these has he made any effort to do.

The defendant is not subject to the burden of proving that the loss would have happened, whether he had done his duty or not. 
The principle of Barmes is still good law and is applicable here in my opinion. Absent proof of self-interest that casts upon the director the burden to prove the entire fairness of an interested transaction, a shareholder-plaintiff must prove by a preponderance of evidence that director negligence did cause some injury and must introduce sufficient evidence from which a responsible estimation of resulting damage can be made. Of course in a case in which the plaintiff proves at trial (or as here it is assumed) that the board was negligent, there will frequently be no conclusive evidence available on the counter-factual question what would have happened if the directors had proceeded prudently. But that fact, while it may properly affect the court's assessment of what is sufficient proof of damages, cannot relieve plaintiff in an arm's-length transaction of its obligation to prove that in fact it was injured by director negligence. ${ }^{148}$

And, because the pre-merger value of Technicolor was $\$ 21.60$ per share, less than the $\$ 23$ per share that Perelman paid, the plaintiffs failed to prove any injury.

Chancellor Allen's analysis was entirely plausible. If, as it appears on its face, the duty of care is a negligence standard, then, as in other cases in which the negligence standard is applied, the plaintiff must prove injury and damages as part of its case in chief. The fundamental principle of "no harm, no foul" applies throughout negligence and, as in basketball, is eminently sensible. If the negligent behavior does not injure anyone, what purpose could possibly be served by triggering the machinery of judicial scrutiny?

What is so interesting about this series of opinions is not only that the Delaware Supreme Court reversed (something they do reasonably frequentiy), but also that it did so in a manner that suggested that it thought that Chancellor Allen fundamentally misunderstood Delaware corporate law and that tort principles have no place. Indeed, it thought that injecting an injury requirement would fundamentally distort the existing structure by losing sight of the underlying purpose of the rule:

Burden shifting does not create per se liability on the part of the directors; rather, it is a procedure by which Delaware courts of equity determine under what standard of review director liability is to be judged. To

$* * *$

I conclude, therefore, as to this first claim that there is no evidence that the defendant's neglect caused any losses to the company, and that, if there were, that loss cannot be ascertained.

Id. at *57-*58 (quoting Barnes v. Andrews, 298 F. 614, 616-18 (S.D.N.Y. 1924)) (omissions in original).

${ }^{148}$ Id. at $* 59$. 
require proof of injury as a component of the proof necessary to rebut the business judgment presumption would be to convert the burden shifting process from a threshold determination of the appropriate standard of review to a dispositive adjudication on the merits.

What is the Delaware Supreme Court up to here? Why does it

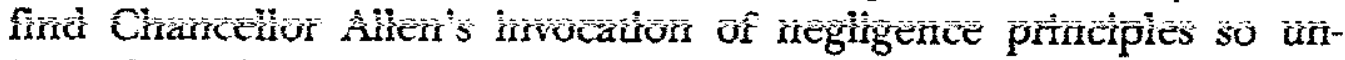
precedented and peculiar? Why, in Allen's opinion, did he need to reach outside of Delaware law for a citation that liability under the duty of care requires proof of injury and damages? Why was there no Delaware case on point?

Our analysis-whatever one thinks of it on its own merits-provides a coherent explanation for the supreme court's opinion. On our analysis, the duty of care is not a negligence rule, but, rather, is intended to be "self-enforcing," with the self-enforcement protected by the business judgment rule. The narrow question posed in Cede is whether to respect the autonomy of the self-governance, not whether the substantive rule of conduct has been breached.

This is a critical question that must be answered prior to the substantive inquiry because it determines the nature of the sanctions. If NLERS control, then sanctions will be nonlegal. If NLERS self-governance is ignored, then the sanctions will be legal.

Once one leaves the domain of self-governance, the court will look closely and review the substance of the transaction or decision. The slogan for looking closely is the "entire fairness" standard. Moreover, if what is at stake is not whether the directors engaged in professional malpractice, but, rather, whether the court will scrutinize the substance of the decision or transaction, then the Delaware Supreme Court's argument that the Chancellor ran two separate questions together is correct. A requirement of proof of damages as part of the plaintiff's case would, indeed, "convert the burden shifting process from a threshold determination of the appropriate standard of review to a dispositive adjudication on the merits."

At the same time, the Delaware ambivalence over whether to understand the duty of care as a negligence rule emphasizes the difficulty' Delaware has in fitting a negligence rule into a system designed to promote self-governance. This still leaves unanswered, however, a key question. Our analysis supports the Delaware Supreme Court's view in Cede that the duty of care should not be viewed as a negligence

\footnotetext{
19" Cede II, 634 A.2d at 371.

Id
} 
rule and that lack of proof of harm should not, by itself, lead to dismissal of the plaintiff's case. But what about the other half of the supreme court's analysis? Why does directorial negligence suffice to defeat the application of the business judgment rule's deference? Why does inadequate process, absent self-dealing, destroy deference to $\mathrm{NL} \overline{\mathrm{K}} \overline{\mathrm{S}}$ governance in $\mathrm{C} e d e$ and $\mathrm{V} a \mathrm{C}$ Gorkom? It is to this question that we now turn.

\section{Limits of NLERS Governance: Midstream Versus Endgames}

As we discussed above in the context of the duty of loyalty, NLERS governance breaks down when the possibility of self-dealing of significant magnitude emerges. The temptation to get seriously rich is too strong for soft (that is, socially acceptable) NLERS sanctions to control, and thus the stronger sanctions of the law are needed.

This provides an explanation for judicial displacement of NLERS governance when there is self-dealing. But what about the cases in which courts intervene under the heading of the duty of care even in the absence of self-dealing? How does that square with our NLERS analysis? Delaware cases such as Smith $v$. Van Gorkom and Cede $\mathcal{E}^{\circ} \mathrm{Co} . \boldsymbol{v}$. Technicolor pose a puzzle for our approach. In both cases, the Delaware Supreme Court imposed a burden on the defendant directors to prove the "entire fairness" of the transaction. Moreover, in each case, the court did not base its holding on any finding of self-dealing by the directors.

One response is to read these as cases in which the court, without saying so, suspected self-dealing although there was insufficient evidence in the record to establish it. On this reading, the argument would be that a bad decisionmaking process is an indication of selfdealing. If so, then even though the court does not say that these are duty of loyalty cases, they really are. Read this way, the cases are consistent with our earlier argument about self-dealing and the limits of NLERS governance.

The problem with such a reading, however, is that the courts really do not seem to think that self-dealing is involved. One detects judicial suspicion of Van Gorkom's behavior, but little sense that they think he is taking something that other shareholders are not getting too. Similarly, in Cede, Chancellor Allen's finding of lack of selfinterest was quite strong: it was a true arm's-length transaction, with one unimportant director disqualified because he was getting a (dis- 
closed) finder's fee from the buyer, and another, the COO, because he was likely to be the new CEO. ${ }^{151}$ The negotiations were run by the current CEO, who was not on speaking terms with the COO, with input from the largest shareholder and a respectable investment bank. It is very hard to see how, if there was self-interest in Cede, there is ever a case of non-selifinteresh.

Suppose, then, that we accept at face value the absence of any finding of self-dealing. What is the court doing prescribing or at least strongly encouraging a particular sort of valuation methodology or procedure for selling the company? One might argue that finance has evolved to the point where informed observers know that certain methods for valuing assets give better answers than do others. On this argument, although there will be differences depending on whom you hire, using the common DCF methodology reduces the variance of the distribution of possible answers. The court might be saying that the directors get to make the decisions about whom to hire and about whom to believe, but they have to use the DCF methodology. This is to read the duty of care as a negligence standard, but one that focuses solely on procedure and not on substance.

The problem with this argument is that unless one views the failure to use the generally accepted DCF methodology as a red flag that signals self-dealing (and thus reduces the argument to the preceding argument), it seems wrong. After all, we leave all sorts of operating choices in which there are complicated but generally accepted methodologies to NLERS governance (for example, what process to use to make steel, how to organize accounts receivable financing, and what sort of distribution network to establish). How is it that we leave the choice of all of these equally complex processes to NLERS governance, except when it comes to valuation decisions when the court decrees that DCF is the required methodology? This would be an odd way to organize the world, as valuation methodologies change as quickly as steel making or distribution methods. Further, once the court adopts a methodology, it is likely to stick with it long after the world has moved on to another. ${ }^{152}$

Consider a common alternative justification: valuation issues involve quintessential shareholder issues rather than corporate operating issues and therefore shareholders have a right both to a particular

1.: Set Cinrrama, 1991 Del. Ch. LEXIS 105, at *7*9.

1:- Compare, for example, the decades-long adherence by Delaware courts to the Delaware block method of valuation in appraisal proceedings, even in the face of enormous developments in valuation methodologies. 
sort of valuation and to participate through their ability to veto significant transactions. Leaving aside the difficulty of figuring out what is a shareholder issue and what is a corporate operating issue, one would still expect that, given the basic incentive compatibility of the corporate form, the directors would involve shareholders when shareholders have something to add. Put differently, the legally enforceable rights that shareholders have to vote on a (limited but important) number of things ${ }^{153}$ is one of the features of the corporate form that renders corporations largely NLERS self-governing. With those structures in place, why would one think that shareholders have legally enforceable rights to participate in valuation decisions (which they do not) or legally enforceable rights to have directors follow particular valuation methodologies? Why is this not just the sort of decision left to NLERS self-governance?

The key to understanding the courts' greater willingness to intervene in these duty of care cases is the realization that they involve the sale of the company, a classic last period problem. ${ }^{134}$ Both the norms and the implicit contracting literatures make clear that otherwise incentive compatible relationships lose that quality once one gets to the last period. Self-dealing is one way in which a game can enter its last period, as the agent encounters the temptation to become sufficiently rich to head off to the slopes. The sale of the company is another way in which the game can enter a final period. Cede and Van Gorkom are both last period cases in which the company is being sold.

And note how the courts intervene. First, they try to get the parties to adopt the procedures that they would have adopted with regard to normal NLERS-governed decisions. When the actors depart from

${ }^{153}$ Voting must be a legally enforceable rule because participants need to be able to make a credible commitment to giving the shareholders the vote when ex ante it is clear that ex post there will be situations in which the managers, for self-interested and entrenchment and empire building reasons, will prefer that shareholders not vote. At the point that reputation and such things get going, they might be enough to constrain bad behavior nonlegally, but in the first period, before such things are built up. the law can play a role by making it a legally enforceable rule.

${ }^{154}$ Jon Macey and Geoff Miller also read Van Gorkom as applying specially to the sale of company context. Jonathan R. Macey \& Geoffrey P. Miller, Trans Union Reconsidered, 98 YALE L.J. 127 (1988). We differ from Macey and Miller in that, for us, the reason that special scrutiny is given in the sale of company context is that it is a last period in which NLERS governance predictably breaks down. The differences between first period, midstream, and endgames has been discussed most explicitly in the context of the debate over LBOs and dual class capital structures. See, e.g., Ronald J. Gilson, Evaluating Dual Class Common Stock: The Relevance of Substitutes, 73 VA. L. REV. 807 (1987); Jeffrey N. Gordon, Ties That Bond: Dual Class Common Stock and the Problem of Shareholder Choice, 76 CAL. L. REv. 1 (1988). 
these generally accepted decision procedures, that is a red flag that something bad is going on (which, because it is the last period, courts were already worried about), and so more intrusive scrutiny is necessary.

This analysis provides an explanation for the Delaware Supreme Court's preoccupation in Smith v. Van Gorkom with Van Gorkom's pending retirement. From a narrow agency cost perspective, Van Gorkom's impending retirement makes him a better agent for the shareholders. After all, he is utterly unaffected by concerns of keeping his job under the new owners. While he was obviously less diversified than most of the shareholders, and had a different time horizon, he did have a sharply focused financial incentive to maximize share value, and much better incentives than the managers who thought that they might like to keep their jobs.

The court's focus on Van Gorkom's retirement, however, makes more sense once one realizes that the retirement signals that Van Gorkom is in his last period of play-and therefore beyond the reach of NLERS governance-which is why the court must look more closely. In Cede, in which there was even less of a specter of selfdealing, the court similarly looked closely (that is, entire fairness scrutiny), simply because, we argue, it was the last period.

Our framework thus provides an explanation for the court's analysis in Van Gorkom and Cede. But, that said, our analysis likewise shows that, on their own terms, the decisions are badly flawed. Van Gorkom applies a negligence standard and does so without regard to whether the circumstances were midstream or endgame and without regard to the robustness of the NLERS. In failing to distinguish the last period case from other business decisions, the cases appear to apply a negligence standard across the board, thereby threatening the domain of NLERS governance. Rather than being a nearly impenetrable barrier, the presumption of the business judgment rule now appeared highly penetrable. The outcry that followed the court's decision in Smith $v$. Van Gorkom underscored the extent to which corporate decisionmakers viewed the court as having fundamentally changed the rules. The legislative response, Delaware General Corporation Law section 102 (b) (7), largely reinstated the status quo ante, effectively ending Delaware's experiment with a negligence based duty of care.

\section{Some Other Puzzles: Asset Purchases, Failed Mergers, and "Just Saying No"}

This distinction between midstream and last period decisions also 
provides a nice explanation for several of the many dogs that do not bark in corporate law. Consider the aspects of mergers and acquisitions that reliably do not require shareholder involvement and do not trigger litigation. First, the decision to buy another company or to expand operations requires less shareholder approval and generates far less judicial scrutiny than a decision to seî. Aithough a merger requires shareholder approval by both sets of shareholders, the requirement is easily avoided by structuring the transaction as a triangular merger. Similarly, while a sale of all or substantially all of the assets requires approval by the shareholders of the selling company, no approval is required by the shareholders of the buying company, even if the result is to triple the size of the company.

Second, consider the litigation that does not emerge when an acquiring company takes a fundamental change in direction by buying assets largely unrelated to those already owned and the transaction flops. The landscape is littered with the carcasses of failed acquisitions, many of which have cost shareholders vast amounts of money. The same is true with bad investment decisions. With perfect 20-20 hindsight, it is obvious to the whole world that the directors who approved the deal must have been deluded. On any sort of selfrespecting negligence rule, one would expect cases and recoveries. Yet there are almost none.

Even if one took the view that imposing liability on directors for negligence makes little sense because it will directly or indirectly come out of the corporate treasury (and thus pro rata from the shareholders themselves), one would expect other manifestations. For example, courts might closely scrutinize such cases in the context of injunctive relief, or impose liability in favor of creditors when firms go bankrupt.

Why does litigation not happen? One cannot distinguish the situations on the grounds of the amount at issue, the nature of the decision, or the effect on shareholder interests. Rather, the prime distinction is that buying assets or investing in new products, while creating the same horrible risks for shareholders as selling assets, does not raise a final period problem. Because, in the absence of a final period problem (generated either by the likelihood of self-dealing or sale of the company), there is no reason to think that NLERS governance breaks down, and the courts stay out.

Similarly, one finds an asymmetry in the Delaware courts' response to the conflict of interest faced by target management confronted with a hostile bid. As Stephen Fraidin and Jon Hanson note:

On one hand, [the Delaware courts] have shown near limitless defer- 
ence to target boards (and thus little concern for the conflict of interest), provided the boards reject all bidders. As corporate commentators sometimes quip, target boards are permitted to "just say no." On the other hand, once a board decides to sell its firm, courts often intervene to prevent the board from giving any one bidder undue advantage over wher actual or potential bidders. The goal is to foster a robust takeover

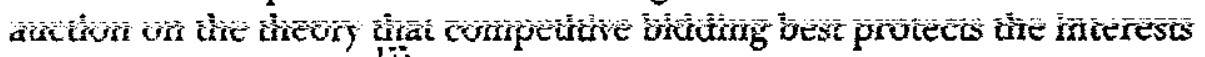
of target shareholóers.

From our perspective, this asymmetry is to be expected, is consistent with the deep structure of Delaware corporate law, and is justified. On the one hand, the decision to "just say no" is a typical midstream decision which, as we have seen above, is governed by NLERS. By contrast, the decision to sell the firm creates an endgame, a scenario in which, as we have seen, NLERS can lose their self-enforcing properties.

\section{E. Delaware's Demand Requirement}

Derivative litigation in Delaware (and elsewhere) requires that a shareholder make a demand on the board of directors to pursue a claim before the shareholder can pursue the claim on the corporation's behalf, unless such a demand would be futile. Because shareholders (correctly) believe that a board is unlikely to pursue a claim against one of its own, shareholders hardly ever make a demand. The first battle in derivative litigation over alleged directorial misconduct is thus typically a defendant's motion to dismiss for failure to make a demand, and the first ruling is the court's determination whether demand would have been futile. This demand requirement strikes many observers as a perverse sort of early summary proceeding that oddly occurs before plaintiffs have had a chance to take any discovexy.

An NLERS analysis provides a basis for a demand requirement. The demand requirement is nothing more, and nothing less, than an early determination of whether NLERS governance is functioning or has broken down. Unless plaintiffs can give the court reason to think that NLERS governance has broken down, demand of the board is required, and the board's decision (inevitably not to pursue the claim)

I"Stephen Fraidin \& Jon D. Hanson, Toward Unlocking Lockups, 103 YALE L.J. $1739,1741-42$ (1994) (foomotes omitted).

Site PrincIPLes OF CORPORATE GOVERNANCE, supra note $82, \$ \$ 7.03,7.10 \&$ crits. 
is reviewed under the business judgment rule. ${ }^{157}$ In other words, the normal deference to the jurisdictional boundary continues. Even if NLERS governance breaks down because of a conflict of interest, the board may be able to reassert control if it is able to reestablish the conditions of NLERS governance. ${ }^{158}$

According to the leading Delaware case, Aronson v. Lewis, demand will be excused if "under the particularized facts alleged, a reasonable doubt is created that... the directors are disinterested and independent." ${ }^{159}$ Alternatively, demand will be excused if the pleading creates a reasonable doubt that "the challenged transaction was otherwise the product of a valid exercise of business judgment." "Thus, under the first prong, demand will be excused if there is a reasonable likelihood of self-dealing or a similar conflict of interest. ${ }^{161}$ This, of course, is precisely the circumstance in which one would expect normal NLERS self-governance to break down because it is potentially a final period.

Indeed, under the traditional approach to the demand requirement, the first prong was the only prong. The key was to establish a reasonable basis for suspecting lack of independence or self-dealing. If the plaintiffs succeeded, demand was excused and the plaintiffs could proceed with the case. If not, demand was required, and the case was dismissed. If the plaintiffs subsequently made demand, the board typically rejected it, a decision that would ultimately be protected by the business judgment rule. This is the structure that our approach would predict.

But, as we discussed earlier, negligence concepts somehow crept into Delaware's analysis of the duty of care. Once that happened, they also crept into Delaware's interpretation of the demand requirement. Thus, demand will be excused under the second prong of Aronson when, according to the Delaware Supreme Court in Brehm, "the par-

${ }^{157}$ Levine v. Smith, 591 A.2d 194, 200 (Del. 1991); Spiegel v. Buntrock, 571 A.2d 767, 773-74 (Del. 1990); Aronson v. Lewis, 473 A.2d 805, 814-18 (Del. 1984).

158 Zapata Corp. v. Maldonado, 430 A.2d 779, 785-86 (Del. 1981).

159473 A.2d at 814.

${ }^{160} I d$.

${ }^{161}$ See, e.g., id. at 808-09 (questioning the business purpose of an employment agreement with high compensation and of an interest-free loan); Abajian v. Kennedy, No. 11425, 1992 WL 8794, at *5*8 (Del. Ch. Jan. 17, 1992) (finding that the issuance of preferred stock to a favored shareholder excused demand); Good v. Texaco, Inc., No. 7501, 1984 WL 8220, at *6 (Del. Ch. May 14, 1984) (finding that the agreement giving Texaco directors the right to direct how the Basses would vote their preferred shares sufficed to excuse demand). 
ticularized facts in the complaint create a reasonable doubt that the informational component of the directors' decisionmaking process, measured by concepts of gross negligence, included consideration of all material information reasonably available. ${ }^{\text {"6i2 }}$

This interpretation of the second prong of Aronson raises precisely

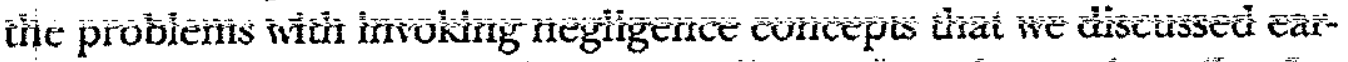
lier. Uniess the presence of "gross negligence" is taken to be a flag for self-dealing or a related conflict of interest (in which case it is duplicative of the first prong), then the presence of gross negligence does not track the breakdown of NLERS self-governance. Many business decisions are made with gross negligence. Think, again, of the worst mergers in history. Yet, reliably, these blunders do not trigger litigation.

As before, this invocation of negligence concepts is unfortunate because it is confusing. In practice, the Delaware courts seem to ignore any ordinary legal meaning of gross negligence, which, on our model, is exactly what one would expect. So long as the relevant Delaware actors understand that a stupid sale of a division or a stupid acquisition by merger will not be held to be a breach of the duty of care, no matter how grossly negligent the decision (absent "fraud, illegality or conflict of interest"), the gross negligence language does little mischief. The effectiveness of Delaware's law as a facilitator of NLERS self-governance would be threatened only if people started taking that language seriously and finding a breach of the duty of care for gross negligence.

At the same time, the NLERS analysis provides a second basis for excusing demand. Excusing demand when the board faces a conflict of interest is justified because conflicts of interest pose the clearest case for a breakdown of NLERS governance caused by a potential last period. But, if this is right, excusing demand is also justified in other last period contexts, such as when the board is selling the company.

Interestingly, Delaware has arrived at just this result, without articulating it as an alternative basis for excusing demand. Van Gorkom, for example, is not a case in which demand is excused, but, rather, a case in which demand is not required. In the typical last period mergers and acquisitions case, as in Van Gorkom, demand is excused because the cause of action is construed as direct, not derivative, as it affects shareholders' individual interests qua shareholders. At the

"B Brehm v. Eisner, 746 A.2d 244, 259 (Del. 1999) (citing Aronson, 473 A.2d at 812). 
same time, demand is required (and typically not excused absent "fraud, illegality or conflict of interest") in the typical sale of a division or purchase of a company context. By characterizing the last period mergers and acquisitions context as a direct rather than derivative suit, Delaware is able to tailor its level of scrutiny to the likelihood of NLE E $\bar{R} \bar{S}$ break̄own.

\section{A LoOSe END: Why Do Delaware Judges Talk So MUCh? THE COURTS AND THE TRANSMISSION OF NLERS}

The above account explains the business judgment rule and its two principal last period limits, self-dealing and the sale of the company. But the above account leaves one major feature of our corporate law unexplained. If the business judgment rule is best underistood as a jurisdictional or justiciability rule, why all the talk about the duty of care of directors? The employment-at-will doctrine is a much cleaner justiciability rule. It says to complaining employees: "courts are not going to interfere; go away." One does not read long accounts of the duties of employers to treat the employees fairly and not to discharge them without cause. Why all that talk in corporate law, especially in those cases in which no injunction is granted and no liability is imposed?

A cynical view is that it is all cant, an insincere attempt to justify excessive deference to managers. This, roughly speaking, characterizes the attitude of those who thought that the result of interstate competition for charters was a race to the bottom, a pandering to managers by Delaware judges determined to increase business for Wilmington lawyers.

Mel Eisenberg suggests a different explanation. Using Meir DanCohen's notion of acoustical separation, Eisenberg suggests that the law is speaking to two audiences. ${ }^{163}$ The duty of care is directed to corporate directors and seeks to encourage them to act well. The business judgment rule is directed to judicial decisionmakers and tells them not to sanction any but the most egregious departures from the duty of care.

One problem with the explanation is that the source of much of the talk about the duty of care is not the legislature, which in fact has been almost entirely silent on the matter, but the judges themselves. ${ }^{1 " 1}$

\footnotetext{
${ }^{163}$ Eisenberg, supra note 97, at 461-67.

${ }^{16-4}$ With the exception of the Delaware legislature's prompt enactment of DEL. CODE ANN. tit. 8, § 102(b) (7) (Supp. 2000).
} 
If the judges are the ones who do all the talking, and lawyers are listening on behalf of their clients, it is not clear where the acoustical separation appears.

Of more concern is that the observation provides no explanation for why we observe this peculiar mix here. After all, one seems not to

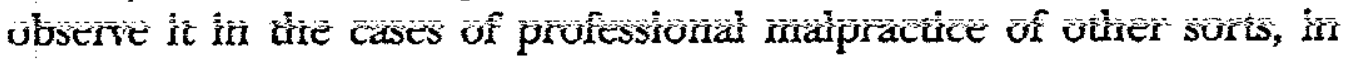
which the articulation of the duty of care is typically accompanied by significant legal liability. One also does not observe it in the employment context, in which the refusal to impose legal liability is accompanied by tactful silence on the employer's nonlegally enforceable duties to its employees.

We have argued above that the duty of care is best understood as an NLERS whose legal nonenforceability is provided by the business judgment rule. If this is right, we come to the question of the role of Delaware judges in the transmission of NLERS. As suggested earlier, the first, and clearly most important, transmission device for NLERS is competitive markets. While managers will, in the first instance, choose the NLERS for their firm, they do so against the background of a market check. In competitive markets, firms that adopt productive NLERS thrive. Those who adopt dysfunctional NLERS do not.

Beyond competitive markets, there are a variety of transmission mechanisms. Business schools and consultants play a significant role. Directors who serve on more than one board cross-fertilize like bees carrying pollen from blossom to blossom. Lawyers likewise often see a wide range of variations and develop notions of best practice.

Where do the Delaware judges fit in here? If one takes management buyouts ("MBOs") as an example, one finds that the use of a special committee, while clearly recommended by the court, is neither necessary nor sufficient for the validity of the transaction. ${ }^{165}$ The practice of using special committees thus seems to be an NLERS. The Delaware courts, during the 1980 s, played a central role in articulating and encouraging the use of special committees in MBO transactions, often by criticizing or complimenting particular lawyers and directors without imposing any sanction.

Similarly, the Delaware encouragement of the use of independent directors in conflict transactions, although again neither necessary nor sufficient for validity, can likervise be understood as an effort to spread the emerging best practice. In that context, indeed, the

Wh For a detailed examination of the Delaware MBO cases, see Rock, supra note 78, at 1028-63. 
courts' role may be to spread best practice among companies and, in particular, from large, well-counseled companies to smaller firms.

In both cases, if the Delaware courts are, indeed, playing a role in the transmission of NLERS, they are doing so within a narrow compass. The NLERS they encourage are within the scope of lawyers' traditional expertise: process-based, institutionally subtle governance mechanisms designed to control complicated conflicts of interest. With judges typically drawn from the Delaware corporate bar, or, when not, rather quickly socialized by those who were, they occupy an odd sort of insider/outsider position. From years of corporate practice, they typically know a lot about the way the Delaware corporate world works. But, at the same time, they develop a sense of the limitations of the judicial role, especially with respect to encouraging excellent management or punishing bad management. This puts them in the position of having at least some credibility to influence this specialized set of NLERS, especially in publicly held corporations, through criticism unaccompanied by legal sanction.

By contrast, judges in medical malpractice cases do not exercise the same degree of restraint in imposing sanctions for negligent conduct (in a context in which norm governance is impossible). From the other direction, judges in at-will employment cases typically have neither the background nor the disposition to go beyond dismissing the suit to give a judicial sermon on appropriate conduct.

But this explanation, if correct, poses a challenge for two types of judicial attempts to promulgate particular NLERS: sales of control and compensation. In this regard, return to Gimbel ${ }^{166}$ and $\mathrm{Brehm}^{167}$ (Ovitz/Disney). In Gimbel, the chancery court criticized the process by which managers sold a wholly owned subsidiary. In Brehm, the supreme court criticized the process by which the board decided on compensation for Ovitz, a new employee. The puzzle is this: While one can argue that judges have particular expertise in designing or approving governance mechanisms to control conflicts of interest, they know nothing about how to sell companies or hire employees.

One response is to say that it is the whiff of conflict of interest that sets the hortatory juices flowing. Thus, it is the fact that compensation of senior executives so often involves conflicts of interest between board and executive that explains the court's interest in Brehm. Similarly, the fact that sales of control are so often suffused with directorial

${ }^{166}$ Gimbel v. Signal Cos., 316 A.2d 599 (Del. Ch.), affd, 316 A.2d 619 (Del. 1974).

${ }^{167} 746$ A.2d at 259. 
conflicts of interest explains the court's greater willingness to lecture on the proper process for selling a company than about the proper process for controlling perishable inventory, or some other equally complex internal control process.

\section{CONCLUSION}

In his seminal work on the theory of the firm, Ronald Coase described firms as islands of conscious power. These islands were surrounded by seas, representing unconscious power, namely markets. In markets, the invisible hand was at work, and the functioning of markets occurred without leaders exercising control. Coase's original construct has been developed over the years in the work of Williamson, Grossman and Hart, and others. We base our theory of corporate law on this theory and make the claim that the metaphorical boundary separating the seas and the land represents a jurisdictional boundary as well. In markets, contracts reign supreme, guided by judicial or other third-party enforcement mechanisms. In firms, norms or selfgoverning rules and standards guide behavior.

In this paper we argue that corporate law can be viewed as a remarkably sophisticated mechanism for facilitating self-governance by NLERS. In our approach, the focus is on the corporation as an operating business entity and NLERS as a mechanism for ensuring that centralized management has the freedom to act to maximize shareholder value. Here the executive officers have a number of key functions. First, they determine the core of the firm, which we identify as the collection of assets over which the corporation must have residual rights of control in order to maximize its value. Second, they determine the boundaries of the firm by determining which activities to bring inside the firm and which to leave in markets. The choice between transacting in markets versus bringing transactions within firms is essentially the choice between using contracts as a governing device versus using the authority structure of the firm's hierarchy. Finally, the executive officers determine the governance mechanisms that protect the investments of the parties who invest their time and energy in developing the assets and activities that are brought inside the firm.

Since the arrangements that the parties make with the corporation are necessarily incomplete, they are not contracts as traditionally understood. The boundaries of the firm are thus a demarcation or jurisdictional line distinguishing relationships in which disputes are resolved by third-party enforcement from relationships that are in- 
tended to be self-enforced within the firm.

Our approach breaks with the traditional agency approach that focuses on the problem of bringing the interests of directors into alignment with the interests of shareholders. In this view, particularly

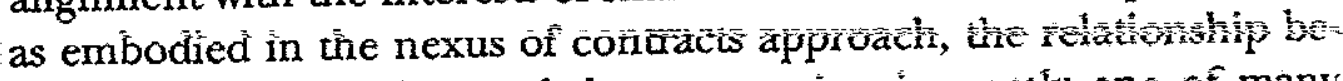
tween the shareholders and the corporation is merely one of many contractual or contractual-type relationships. Limited liability, free transferability, and to a lesser extent legal personality establish the contours of the shareholders' "contract" with the firm. These three features of the firm, along with centralized management, are generally listed as the defining features of the corporation. In the agency model, centralized management is less important since it is viewed as outside of the shareholders' contract with the firm. In our model, centralized management is the most important of the four factors. This shift has fundamental implications for how one understands corporation law.

So how does corporation law facilitate the establishment and maintenance of NLERS governance? The giant first step is the corporate form itself. Centralized management is a statutory creation, with the directors managing the business and affairs of the corporation. By creating the foundations for the firm to operate as a hierarchy, corporate law answers the question of who gets to "run" the company. The executive officers, appointed by the directors, "run" the company, exercising the residual rights of control over the core capital assets. In the close corporation, with the overlap of directors and shareholders, the shareholders are the "owners" in the sense of exercising the resid. ual rights of control. In the public corporation, however, directors and not dispersed shareholders are the owners in that they exercise control over assets.

But the statutory form that so ably protects centralized management nonetheless provides the dispersed shareholders of the public corporation with ownership-type claims not available to any of the other stakeholders that contract with the firm. If the directors fail to maximize the shareholders' residual claims, they can be voted out. The fact that only shareholders get to vote is thus critical in making directors the trustees for shareholders and no other group.

Finally, the statutory form aligns the interests of the directors with the interests of the shareholders, mitigating the potential for opportunism. This is accomplished by assigning voting rights to shareholders to approve extraordinary transactions and through the general prohibitions of non-pro-rata distributions that limit the directors' abil- 
ity to favor one group of shareholders over another.

Our discussion of NLERS explains why these must be legal terms. When the gains of opportunism can be very large, NLERS sanctions might not be sufficient. Similarly, the ability of NLERS governance to restrain opportunism assists our understanding of the workings of fiduciary duty law. From this perspective, the duty of loyality coniplements the statutory limitations on non-pro-rata distributions. Each of the major aspects of the duty of loyalty blocks one of the methods by which faithless fiduciaries can enrich themselves. When a one-shot, lucrative self-dealing transaction can allow a fiduciary to retire outside of the reach of NLERS' soft sanctions, the tougher legal sanctions are required.

But even here, corporation law relies heavily on NLERS governance. For example, Delaware doctrine emphasizes the role of special committees in approving self-interested transactions, MBOs, and parent-subsidiary mergers. In so doing, it shifts the burden from directors whose self-interest is disabling to those who are likely to be constrained by NLERS' sanctions. The end result is to strengthen the primacy of NLERS governance.

Perhaps the most important contribution of our analysis is to explain the puzzle of the duty of care, a doctrine that lies at the heart of modern corporate law. The directors' duty of care looks like a negligence standard, yet it is not. A number of commentators have pointed out that the paucity of cases in which directors are found to have violated their duty of care either means that directors are the most careful folks on the planet or, more likely, that something else is going on. Our theory explains both "what else is going on" and why "what else is going on" is so critical.

The modern theory of the firm offers the foundations for the explanation. In these models, transactions are brought inside the firm precisely because governance by contract is inferior to selfgovernance. From this perspective, Delaware's operationalization of the duty of care acts as a jurisdictional boundary. Without respect for the boundary, centralized management could not operate as it does and the heart of NLERS governance would be threatened.

Corporate law's alternative to second guessing is to have a highly undemanding standard of conduct. The traditional implementation of the business judgment rule avoided the trappings associated with a negligence rule: "courts will not step in and interfere with honest business judgment of directors unless there is a showing of fraud, illegality or conflict of interest." Somewhere along the line, negligence 
language began to creep into the standard of review. The Delaware court fully articulates its negligence test only with Smith $v$. Van Gorkom and Cede.

Our theory helps explain why those cases represent two of the extremely rare occasions when the court found the defendant board's behavior to be negligent, thereby violating their duty of care. Both were end-period cases, a time when NLERS sanctions are at their weakest. Note, in Van Gorkom, how much the court focused on the CEO's pending retirement. ${ }^{168}$ Similarly, our theory explains why the gang at Signal, using the same sloppy method of operation, got off easy in Gimbel, ${ }^{169}$ when they were only selling a division perhaps at too low a price, compared to Weinberger $v$. UOP. ${ }^{170}$ Unlike Gimbel, the plaintiffs win in Weinberger because of the conflict of interest and selfdealing between parent and partly owned subsidiary that permits legal intervention. In the former case, NLERS governance is sufficient; in the latter case, it is not.

While our framework provides an explanation for the court's analysis in Van Gorkom and Cede, our analysis likewise shows that, on their own terms, the decisions are flawed. Van Gorkom applies a negligence standard and does so without regard to midstream or endgame status and without regard to the robustness of the NLERS. In failing to distinguish the last period case from other business decisions, the cases âppear to apply a negligence standard across the board; thereby threatening the domain of NLERS governance.

The outcry that followed the court's decision in Smith $v$. Van Gorkom underscored the extent to which corporate decisionmakers viewed the court as having fundamentally changed the rules. The legislative response, section 102(b) (7), largely reinstated the status quo ante, thereby ending Delaware's experiment with a negligence-based duty of care. Alas, the language remains, but the standard of review in effect is again more consistent with the alternative articulation that requires "a showing of fraud, illegality or conflict of interest." Although drafted in response to pressure from the corporate community, section 102(b) (7) provides a reasonable solution to the problem created by the courts, at least when the remedy is damages.

${ }^{168}$ Smith v. Van Gorkom, 488 A.2d 858, 866 (Del. 1985) ("It is noteworthy in this connection that [Van Gorkom] was then approaching 65 years of age and mandatory retirement.").

${ }^{169}$ Gimbel v. Signal Cos., 316 A.2d 599 (Del. Ch. 1974).

${ }^{170} 457$ A.2d 701 (Del. 1983). 